\title{
Viewpoints on Acid-Induced Inflammatory Mediators in Esophageal Mucosa
}

\author{
Karen $\mathrm{M}$ Harnett, $\mathrm{PhD}^{1}$, Florian Rieder, $\mathrm{MD}^{2}$, Jose Behar, $\mathrm{MD}^{1}$ and Piero Biancani, $\mathrm{PhD}^{1 *}$ \\ ${ }^{1}$ Department of Medicine, Rhode Island Hospital and Brown University, Providence, RI, USA, ${ }^{2}$ Department of Pathobiology, Lerner Research \\ Institute, Cleveland Clinic Foundation, Cleveland, Ohio, USA
}

We have focused on understanding the onset of gastroesophageal reflux disease by examining the mucosal response to the presence of acid in the esophageal lumen. Upon exposure to $\mathrm{HCl}$, inflammation of the esophagus begins with activation of the transient receptor potential channel vanilloid subfamily member-1 (TRPV1) in the mucosa, and production of IL-8, substance P (SP), calcitonin gene related peptide (CGRP) and platelet activating factor (PAF). Production of SP and CGRP, but not PAF, is abolished by the neural blocker tetrodotoxin suggesting that SP and CGRP are neurally released and that PAF arises from non neural pathways. Epithelial cells contain TRPV1 receptor mRNA and protein and respond to $\mathrm{HCl}$ and to the TRPV1 agonist capsaicin with production of PAF. PAF, SP and IL-8 act as chemokines, inducing migration of peripheral blood leukocytes. PAF and SP activate peripheral blood leukocytes inducing the production of $\mathrm{H}_{2} \mathrm{O}_{2}$. In circular muscle, PAF causes production of IL-6, and IL- 6 causes production of additional $\mathrm{H}_{2} \mathrm{O}_{2}$, through activation of reduced nicotinamide adenine dinucleotide phosphate (NADPH) oxidases. Among these, NADPH oxidase 5 CDNA is significantly up-regulated by exposure to PAF; $\mathrm{H}_{2} \mathrm{O}_{2}$ content of esophageal and lower esophageal sphincter circular muscle is elevated in human esophagitis, causing dysfunction of esophageal circular muscle contraction and reduction in esophageal sphincter tone. Thus esophageal keratinocytes, that constitute the first barrier to the refluxate, may also serve as the initiating cell type in esophageal inflammation, secreting inflammatory mediators and pro-inflammatory cytokines and affecting leukocyte recruitment and activity.

(J Neurogastroenterol Motil 2010;16:374-388)

Key Words

Cytokines; Gastroesophageal reflux disease; Platelet activating factor; Substance P; TRPV1

\section{Introduction}

Gastroesophageal reflux disease (GERD) is a common clinical condition, with approximately $20 \%$ of the adult Western population complaining of symptoms at least once per week. ${ }^{1-3}$ The pathophysiology of mucosal injury in GERD remains to be elucidated, but prolonged contact of mucosa with acid contributes to the reflux injury. Several publications have summarized the current understanding of the pathophysiology of GERD, but work on mechanisms of disease has focused primarily on damage to the tight junctions and loss of epithelial integrity in response to acid. $^{4,5}$

It was thought that esophagitis may develop from a chemical injury starting at the luminal surface of the squamous epithelium, progressing through epithelium and lamina propria into the sub-

Received: July 24, 2010 Revised: August 18, 2010 Accepted: August 21, 2010

(c) This is an Open Access article distributed under the terms of the Creative Commons Attribution Non-Commercial License (http://creativecommons. org/licenses/by-nc/3.0) which permits unrestricted non-commercial use, distribution, and reproduction in any medium, provided the original work is properly cited.

*Correspondence: Piero Biancani, PhD

Department of Medicine, Rhode Island Hospital and Brown University, Claverick St, Providence, RI 02903, USA

Tel: +1-401-884-2965, Fax: +1-401-444-5890, E-mail: piero_biancani@hotmail.com

Financial support: This study was supported by NIH grant RO1 DK57030.

Conflicts of interest: None. 
mucosa, resulting in acid-induced death of surface cells, and stimulation of a proliferative response in the basal cells. ${ }^{6}$ This view has recently been challenged; a description of the pathogenetic process has been provided, ${ }^{7}$ proposing that refluxed gastric juice does not directly damage the esophageal mucosa, but rather stimulates esophageal epithelial cells to secrete chemokines. These in turn attract and activate immune cells that damage the mature esophageal squamous epithelial cells ${ }^{7}$ similar to other immune processes of the gastrointestinal tract such as celiac disease where activated lymphocytes damage the mature villous cells. These data are also consistent with previous studies reporting that in experimental esophagitis in animals and in human reflux esophagitis pro-inflammatory cytokine production may underlie the development of erosive esophagitis, ${ }^{8-12}$ which is defined by the infiltration of neutrophils and eosinophils into the mucosa. In addition, in an animal model of acute esophagitis, Paterson et al ${ }^{13}$ showed that acid perfusion caused release of platelet activating factor (PAF) from esophageal mucosa into the lumen and induced significant epithelial injury, prevented by a PAF-antagonist. The data suggest that production of cytokines or chemokines and inflammatory mediators may originate in the mucosa and initiate the inflammatory process.

Except for one recent review, ${ }^{14}$ however, surprisingly little information is available about esophageal inflammation in GERD even though changes at the molecular level may occur prior to macroscopic signs of inflammation. In the following we will examine interaction of acid and esophageal mucosa, leading to production of cytokines and inflammatory mediators, as key events in the onset of esophageal inflammation.

\section{Initial Events in GERD Pathophysiology -}

\section{TRPV1 and acid sensors}

In many inflammatory processes in several organ systems the initial cause of the inflammation is unknown. In esophagitis a likely cause is gastroesophageal reflux, containing $\mathrm{HCl}$, enzymes and bile acids. In this review the effect of one of the components of gastric juice, $\mathrm{HCl}$, has been examined, focusing on the mechanisms of its contribution to inflammation in normal esophageal squamous epithelium.

The squamous epithelial cells of the esophagus may respond to the presence of acid in its lumen through a variety of acid-sensing receptors. The transient receptor potential channel, vanilloid subfamily member-1 (TRPV1, also known as VR1), was origi- nally described in primary sensory neurons as a receptor for capsaicin and related natural irritants (collectively referred to as vanilloids). ${ }^{15}$ TRPV1 is a non-selective cation channel expressed by sensory nerves. It is activated by heat, by the pungent ingredient of chili peppers, capsaicin, or by endogenous hydrogen ions released in tissues during inflammation ${ }^{15}$ or present in gastroesophageal reflux. TRPV1 is now believed to function as a molecular integrator of noxious stimuli, including acids, heat, pollutants with negative electric charge and endogenous pro-inflammatory substances. ${ }^{16}$ Up-regulated TRPV1 expression has been demonstrated in disease states of the gastrointestinal tract such as inflammatory bowel disease, ${ }^{17}$ irritable bowel syndrome ${ }^{18}$ and, more recently, esophagitis. ${ }^{19,20}$ TRPV1 activation in primary afferent neurons evokes the sensation of burning pain and induces neurogenic inflammation by the release of substance $\mathrm{P}$ (SP) and calcitonin-gene-related peptide (CGRP). ${ }^{17,21}$

\section{TRPV1 and inflammation}

TRPV1-induced "neurogenic inflammation" has been examined in several systems, particularly in the airways, and to a lesser

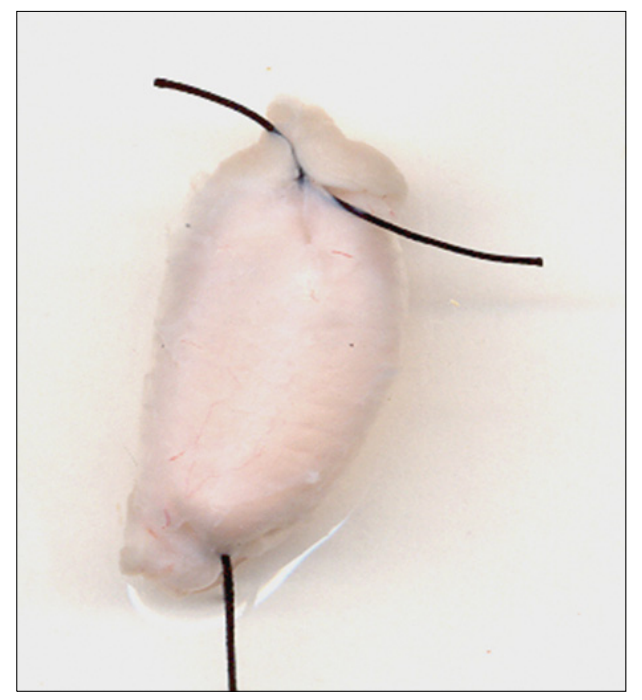

Figure 1. We produced an in vitro model of esophageal inflammation using an esophageal mucosa tube tied at both ends. The tube was created by removing the muscle layers from the esophagus by sharp dissection at the interface between submucosa and circular mucle. It has the squamous epithelium on the inside and the whole submucosa on the outside. $\mathrm{HCl}$ or Krebs buffer was injected inside the tube, which was then kept in oxygenated Krebs buffer at $36^{\circ} \mathrm{C}$ for 3 hours ( $1 \mathrm{~mL}$ Krebs buffer/100 mg mucosa). After 3 hours the supernatant outside the tube was collected and analyzed or used to incubate circular muscle strips. Adapted from Cheng et al. ${ }^{9}$ 
extent in the digestive tract. In the digestive tract most publications have focused on the role of vanilloid receptor in inflammation, with emphasis on stimulation of SP release, ${ }^{22-31}$ or on a role of endopeptidases in degradation of $\mathrm{SP}$, with a resulting decrease in inflammation. ${ }^{32-34}$ In the ileum and colon, TRPV1 is thought to be a mediator of inflammation because, in experimental models of colitis induced by dextran sulphate sodium, ${ }^{35,36}$ or of ileitis induced by Clostridium difficile toxin A28 or anandamide, ${ }^{27}$ inflammation is attenuated in response to TRPV1

A

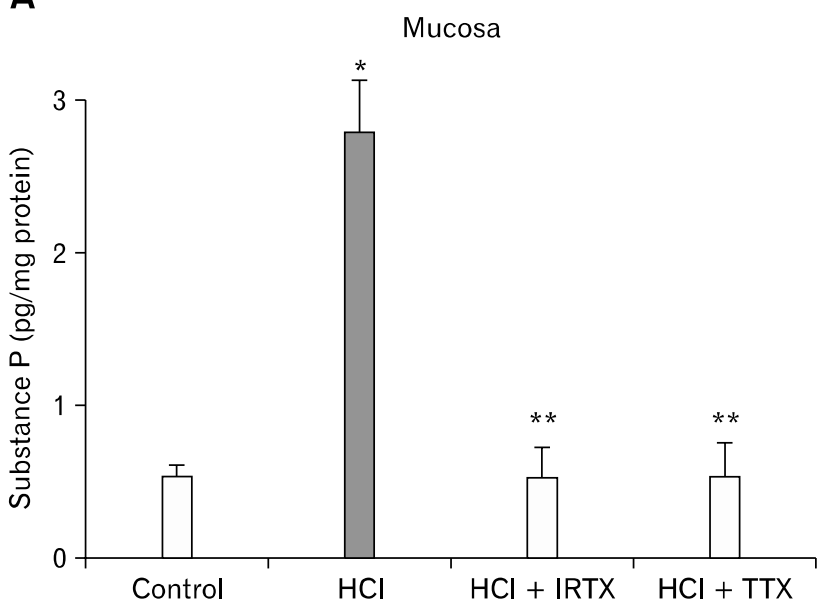

channel blockers ${ }^{35,36}$ or after genetic deletion of TRPV1. ${ }^{37}$

To test whether this acid-sensitive receptor may be the initial mediator of acid-induced inflammation in the cat esophagus, a tubular segment of normal esophageal mucosa and submucosa was removed and tied at both ends to form a mucosal sac (Fig. 1). ${ }^{9}$ The sac was filled with $0.01 \mathrm{~N} \mathrm{HCl}$ (or normal Krebs buffer as controls) and kept in oxygenated Krebs buffer at $37^{\circ} \mathrm{C}$. The medium around the $\mathrm{HCl}$-filled sac (supernatant) was collected after 3 hour incubation and examined for content of inflammatory

B

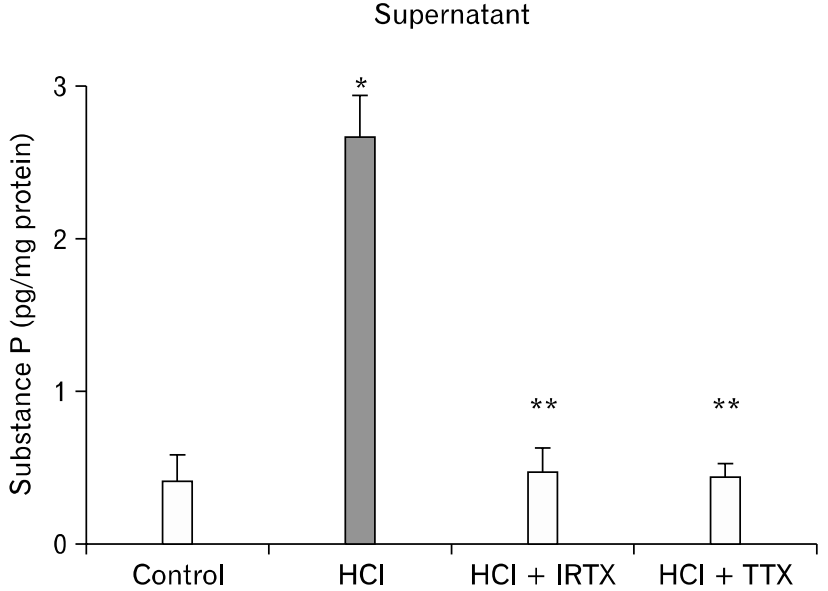

Figure 2. When in vitro mucosa is exposed to $\mathrm{HCl}$ for 3 hours, substance $\mathrm{P}$ levels increase 6-fold in the mucosa (A) and in the supernatant (B) when compared to control $(\mathrm{pH} 7.4)\left({ }^{*} \mathrm{p}<0.05\right.$, ANOVA). The HCl-induced increase in substance $\mathrm{P}$ is abolished by the transient receptor potential channel vanilloid subfamily member-1 receptor antagonist 5 '-iodoresinferratoxin (IRTX) and by the neural blocker tetrodotoxin (TTX) both in the mucosa and in the supernatant $\left(* * \mathrm{p}<0.05\right.$, ANOVA). Bars represent mean \pm SEM of 3 experiments. Adapted from Cheng et al. ${ }^{72}$

A

Mucosa

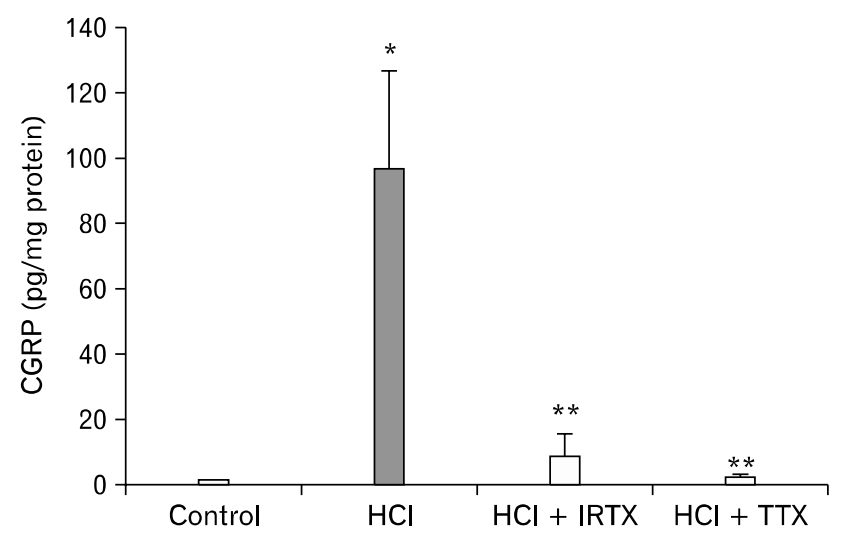

B

Supernatant

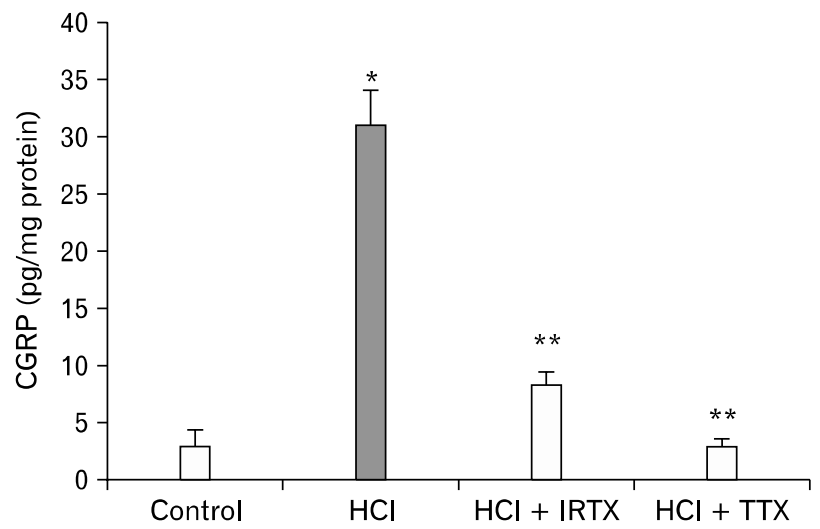

Figure 3. When in vitro mucosa is exposed to $\mathrm{HCl}$ for 3 hours, calcitonin gene related peptide (CGRP) levels increase 200-fold in the mucosa (A) and 10-fold in the supernatant (B) when compared to control ( $\mathrm{pH} 7.4)\left({ }^{*} \mathrm{p}<0.05\right.$, ANOVA). The HCl-induced increase in CGRP is abolished by the transient receptor potential channel vanilloid subfamily member-1 receptor antagonist 5'-iodoresinferratoxin (IRTX) and by the neural blocker tetrodotoxin (TTX) both in the mucosa and in the supernatant ${ }^{* *} \mathrm{p}<0.05$, ANOVA). Bars represent mean \pm SEM of 3 experiments. Adapted from Cheng et al. ${ }^{72}$ 
mediators

\section{Substance $P$ and calcitonin-gene-related peptide}

$\mathrm{SP}$ and CGRP levels increased in mucosal tissue and in supernatant in response to $\mathrm{HCl}$ (Fig. 2 and 3) and the increases were abolished by the TRPV1 receptor antagonist 5'-iodoresinferratoxin (IRTX) or by neural block with tetrodotoxin, suggesting that TRPV1-induced production of SP and CGRP was neurally mediated. Increased levels of neurotransmitters in both mucosa and supernatant imply de novo production of both CGRP and $\mathrm{SP}$, requiring the presence of neural cell bodies in the sac.
In histological sections of esophagus, CGRP immunoreactivity is present in ganglion cells of the myenteric and submucosal plexus, with varying degrees of expression. SP immunoreactivity is detectable in small neurons and fibers, mainly scattered throughout the submucosal plexus. In addition fine SP-positive fibrils are distributed throughout the submucosa with occasional organization into longer and somewhat tortuous fibers (possibly axons) (Fig. 4).

\section{Platelet activating factor}

$\mathrm{PAF}$ is an important chemoattractant and activator of im-
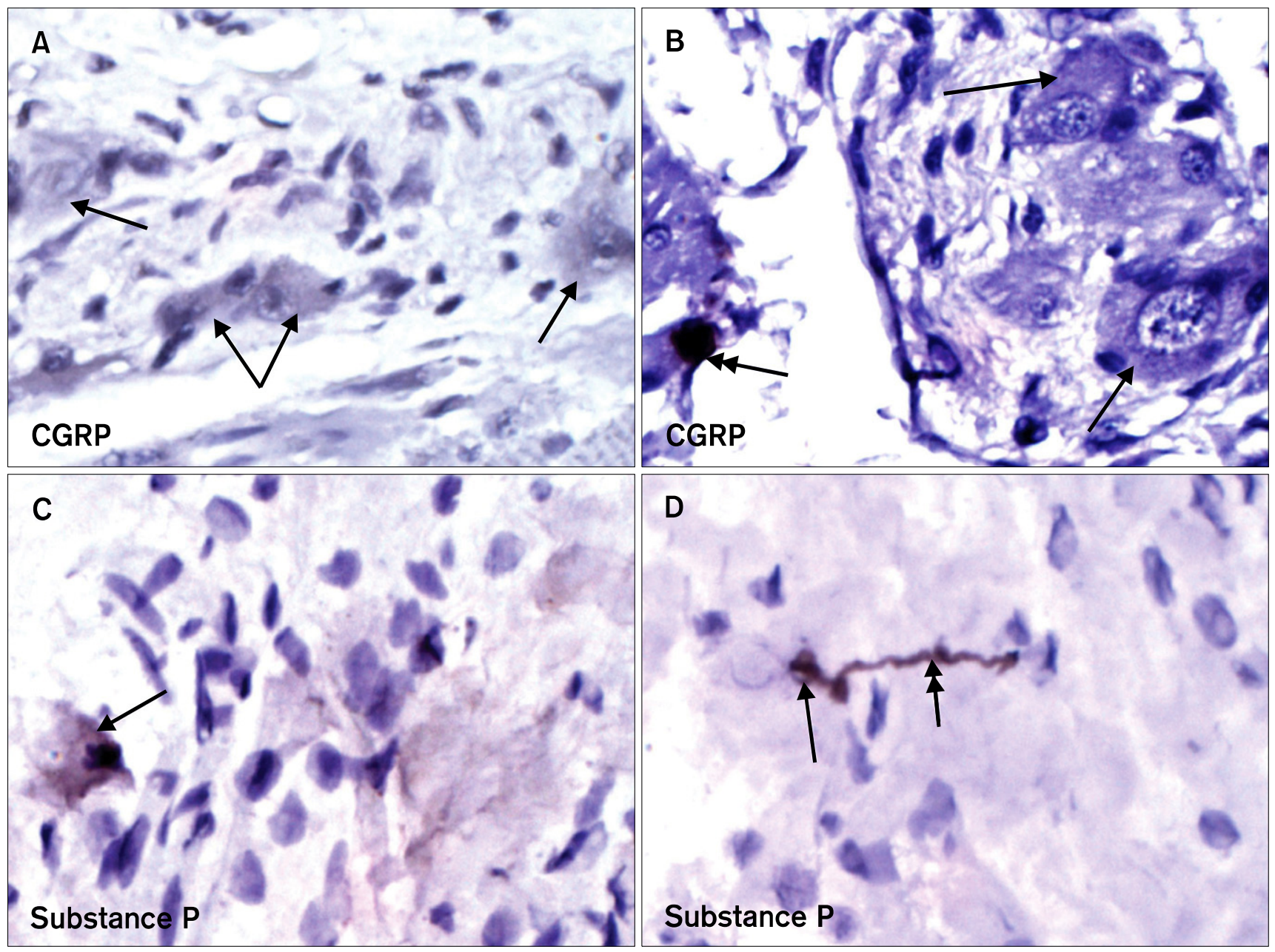

D
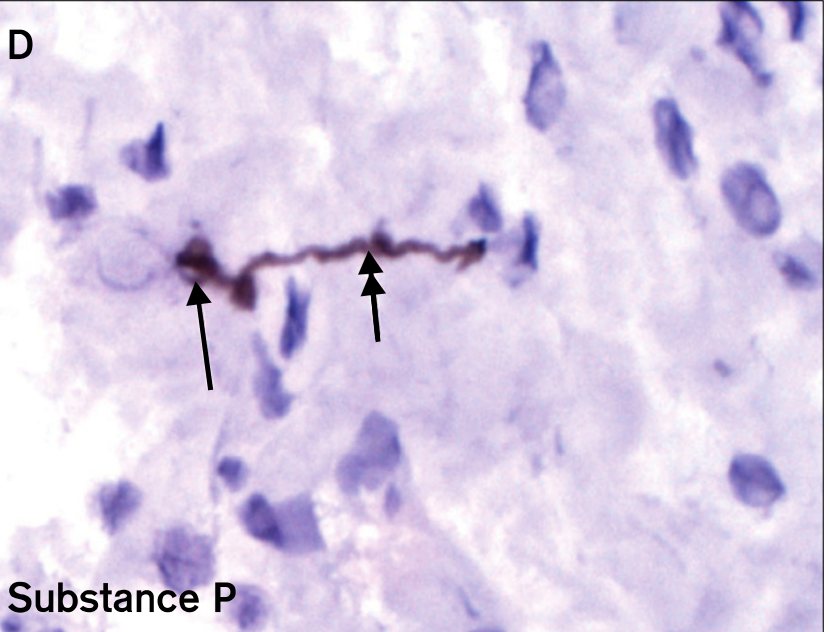

Figure 4. Histological sections of cat esophagus immunostained to detect (A, B) calcitonin gene related peptide (CGRP) or (C, D) Substance P. Immunoreactivity was detected with secondary antibody tagged with horseradish peroxidase (HRP)-conjugated polymer and diaminobenzidine (brown precipitate). Sections were counterstained with Hematoxylin (blue) to depict unlabeled cells. CGRP immunoreactivity was localized in ganglion cells (note nucleoli). Immunoreactivity was low-level and distributed throughout the cytoplasm (arrows) in the submucous plexus, although occasional cells had intense levels of CGRP immunoreactivity (B, double-headed arrow). Substance P immunoreactivity was easily detected in small neurons and fibers scattered throughout the submucous plexus. In addition fine substance P-immunoreactive fibrils were distributed in the submucosa, but occasional longer and somewhat tortuous fibers (probably axons) were identified (B, double-headed arrow). Adapted from Cheng et al. ${ }^{72}$ 
A

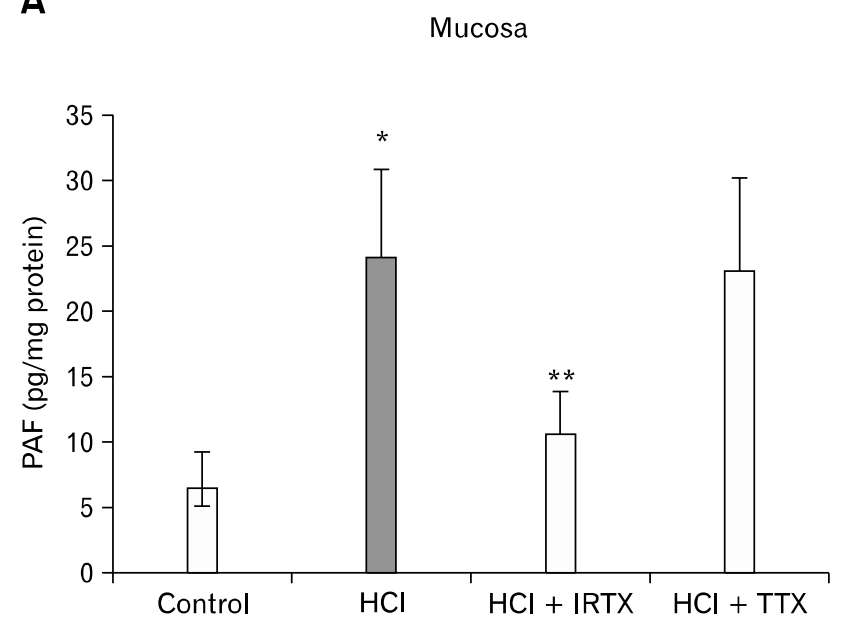

B

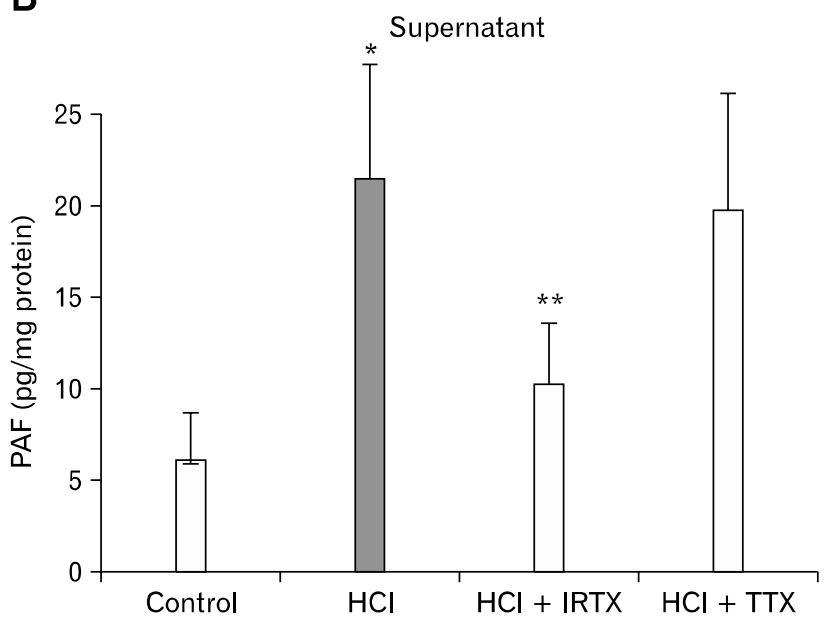

Figure 5. When in vitro mucosa is exposed to $\mathrm{HCl}$ for 3 hours, platelet activating factor (PAF) levels increase 4-5 fold in the mucosa (A) and in the supernatant $(\mathrm{B})$ when compared to control $(\mathrm{pH} 7.4)\left({ }^{*} \mathrm{p}<0.05\right.$, ANOVA). The HCl-induced increase in PAF is abolished by the transient receptor potential channel vanilloid subfamily member-1 receptor antagonist 5 -iodoresinferratoxin (IRTX) $(* * p<0.05$, ANOVA) and not affected by the neural blocker tetrodotoxin (TTX) both in the mucosa and in the supernatant indicating that production of PAF arises from non neural tissues. Bars represent mean $\pm \mathrm{SEM}$ of 3 experiments. Adapted from Cheng et al. ${ }^{72}$

mune cells, with special emphasis on eosinophils. ${ }^{38} \mathrm{PAF}$ is among the most important inducers of eosinophil function and evokes the release of reactive oxygen species by immune cells ${ }^{39,40}$ and by esophageal circular muscle. . $^{41,42}$

PAF levels increased in the $\mathrm{HCl}$-filled mucosal sac and in its supernatant when compared to controls (Krebs filled mucosal sac at $\mathrm{pH}$ 7.4) (Fig. 5). The HCl-induced increase in PAF was abolished by the TRPV1 receptor antagonist IRTX but not by neural block with tetrodotoxin, indicating that production of PAF may arise from non-neural pathways, and most likely from the esophageal epithelium. TRPV1 receptors are present in non-neural cells, such as keratinocytes of the epidermis, ${ }^{43,44}$ in the human keratinocyte cell line $\mathrm{HaCaT}^{43}$ in the human bronchial epithelial cell line BEAS- $2 \mathrm{~B},{ }^{21}$ in bladder urothelium and smooth muscle, ${ }^{45,46}$ liver, ${ }^{47}$ polymorphonuclear granulocytes ${ }^{48}$ and macrophages. ${ }^{49}$

\section{TRPV1 receptors are present in epithelial cells}

The presence of TRPV1 receptor mRNA in esophageal mucosa was shown by reverse transcriptase-polymerase chain reaction (RT-PCR) (Fig. 6A). In feline keratinocytes enzymatically isolated and sorted by flow cytometry to a purity of 90\%-95\% RT-PCR confirms the presence of TRPV1 receptor mRNA (Fig. 6A). Western blot analysis confirms the presence of TRPV1 protein in epithelial cells purified with an epithelial cell selective pan-cytokeratin antibody (Fig. 6B). ${ }^{50-55}$
A

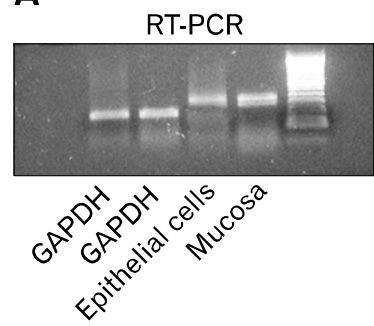

B

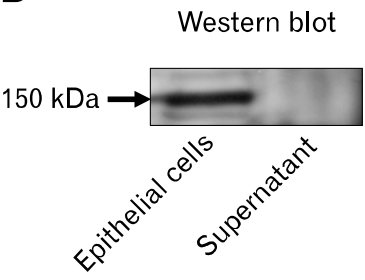

Figure 6. (A) To demonstrate the presence of the transient receptor potential channel vanilloid subfamily member-1 (TRPV1) receptor mRNA in non-neural cells, esophageal epithelial cells were enzymatically isolated and sorted by flow cytometry. Primers were derived from conserved regions of mRNA sequences of humans, rat, dog, mouse guinea pig and rabbit. The BLAST database confirmed that the primers were specific for TRPV1. The band produced using these primers was sequenced, obtaining the sequence of cat TRPV1 with 95\% homology to human TRPV1. Reverse transcriptasepolymerase chain reaction (RT-PCR) confirmed the presence of TRPV1 receptor mRNA in these cat esophageal epithelial cells. (B) To perform a Western blot analysis, the epithelial cells were immunoprecipitated with an epithelial cell selective pan-cytokeratin antibody conjugated with magnetic beads and were isolated by exposing the suspension to a magnetic field as specified by the manufacturer. A $150 \mathrm{kDa}$ band was immuno-blotted with a TRPV1 antibody, confirming the presence of TRPV 1 receptors in these cat esophageal epithelial cells. Adapted from Cheng et al. ${ }^{72}$ 
Production of PAF in esophageal epithelial cells, in response to TRPV1 activation has been confirmed in the human esophageal epithelial cell line HET-1A, where the sequential steps beginning with TRPV1 receptor activation and resulting in PAF production has been elucidated. ${ }^{56}$

\section{TRPV1 receptor activation in the esophageal mucosa inhibits esophageal contraction}

$\mathrm{HCl}$-induced activation of TRPV1 receptors, affects contraction of esophageal circular muscle as electric field stimulation (EFS)-induced contraction of esophageal circular strips was almost abolished by incubation in the supernatant of the $\mathrm{HCl}$-filled mucosal sac (Fig. 7). This supernatant-induced inhibition was reduced when the TRPV1 antagonist IRTX was present inside the mucosal sac, confirming the contribution of functional capsaicin-sensitive TRPV1 receptors in the mucosal wall.

When TRPV1 is activated by the selective TRPV1 agonist capsaicin, the reduction in contraction caused by the sac supernatant is almost abolished by pre-exposure the TRPV1 antagonist IRTX, confirming a role of TRPV1 in this effect. The contraction is restored by the PAF receptor antagonist CV9388 (Fig. 8). This is consistent with release of PAF by epithelial cells in response to activation of TRPV 1 by capsaicin and indicates that $\mathrm{PAF}$ is a major inflammatory mediator affecting circular muscle contraction.

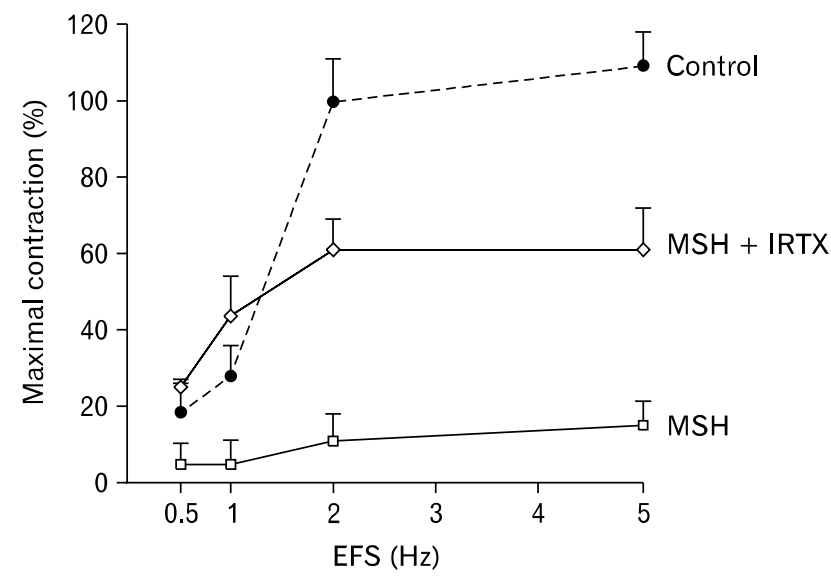

Figure 7. Contraction of esophageal circular muscle (Control) in response to electrical field stimulation (EFS) is almost abolished by supernatant of $\mathrm{HCl}$-filled mucosal sac (MHS). The reduction is reversed by application of the transient receptor potential channel vanilloid subfamily member-1 (TRPV1) antagonist 5'-iodoresinferratoxin (IRTX, $10^{-5} \mathrm{M}$ ) inside the mucosal sac (MHS + IRTX), confirming presence of TRPV1 vanilloid receptors in the mucosal wall. Adapted from Cheng et al. ${ }^{72}$
We conclude that $\mathrm{HCl}$-induced activation of TRPV1 receptors in esophageal epithelial cells results in neurally mediated release of SP and CGRP, and non-neurally mediated release of PAF from the epithelium (Fig. 9).

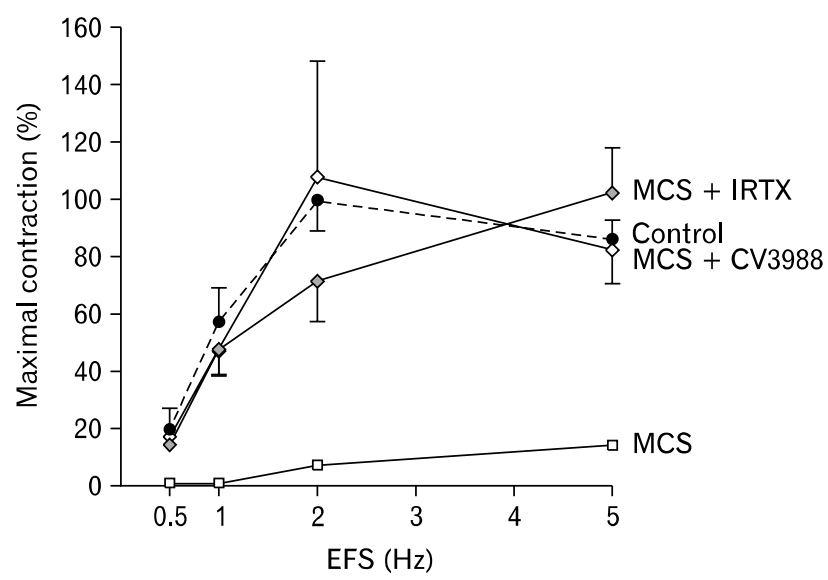

Figure 8. Contraction of esophageal circular muscle (Control) in response to electrical field stimulation (EFS) is almost abolished by supernatant of capsaicin-filled mucosal sac (MCS). The reduction is reversed by application of the transient receptor potential channel vanilloid subfamily member-1 (TRPV1) antagonist 5'-iodoresinferratoxin (IRTX, $10^{-5} \mathrm{M}$ ) inside the mucosal sac (MCS + IRTX), confirming presence of TRPV1 vanilloid receptors in the mucosal wall. The reduction is also reversed by pre-exposure of the muscle to the platelet activating factor (PAF) receptor antagonist CV3988 $\left(\mathrm{MCS}+\mathrm{CV} 3988\left[10^{-6} \mathrm{M}\right]\right)$. This is consistent with release of PAF by mucosa in response to activation of TRPV1 by capsaicin, and suggests that PAF may be the inflammatory mediator most responsible for impairment of EFS-induced (ie, neurally-induced) contraction of circular muscle. Adapted from Cheng et al. ${ }^{72}$

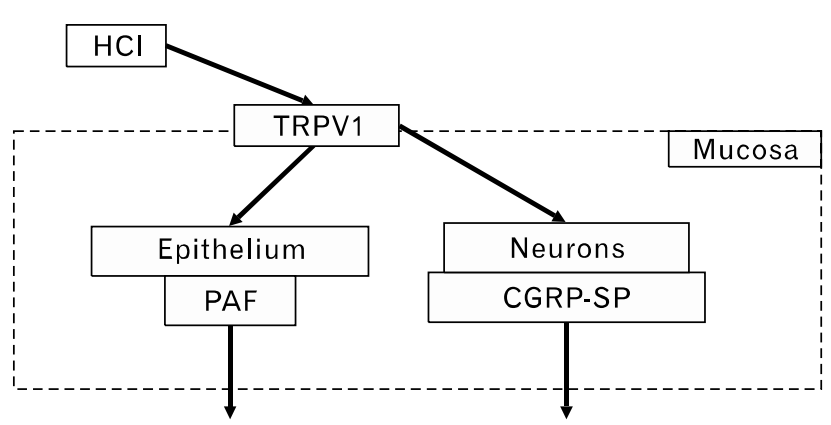

Figure 9. $\mathrm{HCl}$-induced activation of transient receptor potential channel vanilloid subfamily member-1 (TRPV1) receptors in esophageal mucosa results in neurally-mediated release of substance $\mathrm{P}$ (SP) and calcitonin gene related peptide (CGRP), and non-neurally mediated release of platelet activating factor (PAF) from epithelial cells. 


\section{TRPV1-induced release of inflammatory mediators in the human esophagus}

Similarly to the cat, contraction of human esophageal circular muscle is affected by the inflammatory mediators released by the mucosa, rather than by diffusion of $\mathrm{HCl}$ through the mucosal barrier, because when human esophageal circular muscle is directly exposed to $\mathrm{HCl}$ ( $\mathrm{pH} 4,2-3$ hours) no change in EFS-induced contraction occurs (Fig. 10). When the mucosal sac is filled with $\mathrm{HCl}$ at the same $\mathrm{pH}$, however, its supernatant almost abolishes contraction in response to EFS and the inhibition is suppressed by PAF antagonists. This finding is confirmed by direct measurements of PAF that, similarly to the cat, is released in response to $\mathrm{HCl}$ in the esophageal lumen. It is of interest to note that the acid-filled mucosa does not increase production of IL-6 (Fig. 11) and that, although production of IL-1 is increased in the mucosa, IL-1 is not released in the supernatant surrounding the mucosal sac (Fig. 11). These data point to PAF as a major inflammatory mediator released by epithelial cells to affect circular muscle contraction. ${ }^{41}$ PAF inhibits neurally mediated contraction by inhibiting release of acetylcholine from cholinergic neurons (Fig. 12).

The $\mathrm{HCl}$-filled mucosal sac releases PAF into the supernatant ${ }^{41}$ and addition of a PAF receptor antagonist essentially abolished the supernatant-induced inhibition of neurally-mediated circular muscle contraction (Fig. 10). This indicates that $\mathrm{PAF}$ is a major mucosa-derived mediator depressing muscle contraction. ${ }^{41}$ PAF can also activate the esophageal circular muscle to secrete IL-6. ${ }^{41}$ The muscle-derived IL-6 then leads to enhanced production of $\mathrm{H}_{2} \mathrm{O}_{2}$, which in turn induces the secretion

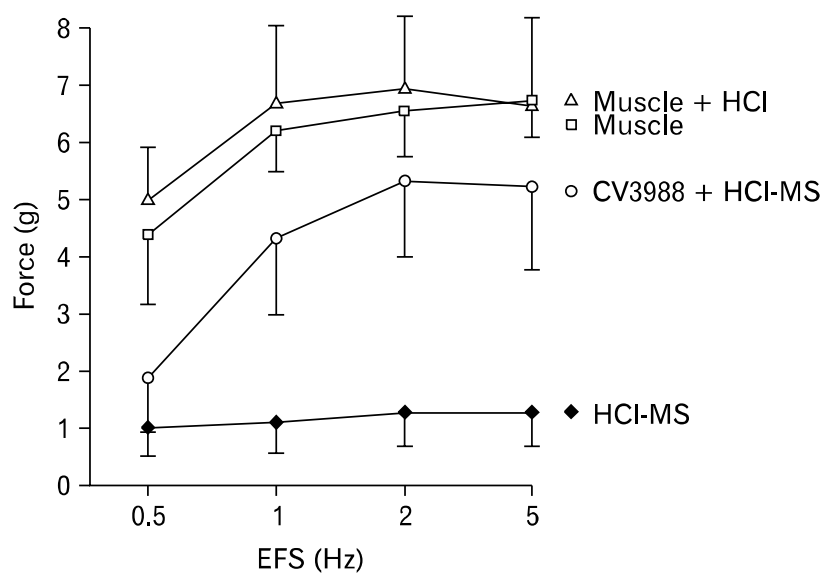

Figure 10. Direct application of $\mathrm{HCl}(\mathrm{pH} 4.0,3$ hours) to circular muscle strips (Muscle $+\mathrm{HCl}$ ) did not change contraction in response to electrical field stimulation (supramaximal voltage, 0.2 $\mathrm{ms}$ ), when compared to untreated muscle (Muscle). Supernatant of $\mathrm{HCl}$-filled mucosa (HCl-MS, pH 4.0, 3 hours), however, almost abolished the contraction $(p<0.05$, ANOVA for comparison of $\mathrm{HCl}-\mathrm{MS}$ to Muscle $+\mathrm{HCl}$ ) The supernatant-induced inhibition was reversed when the competitive platelet activating factor (PAF) antagonist CV3988 $\left(10^{-6} \mathrm{M}\right)$ was added to the supernatant of the HCl-filled mucosal sac (CV3988 + HCl-MS) (p < 0.05, ANOVA for comparison of CV3988 + HCl-MS to HCl-MS). Means \pm SEM are shown for 3 esophagus samples. Modified from Cheng et al. $^{41}$
IL-6

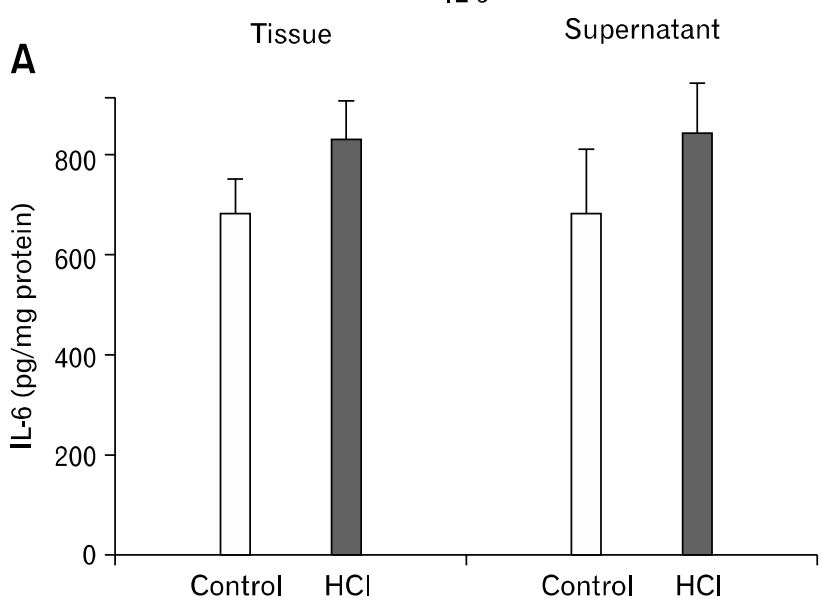

B

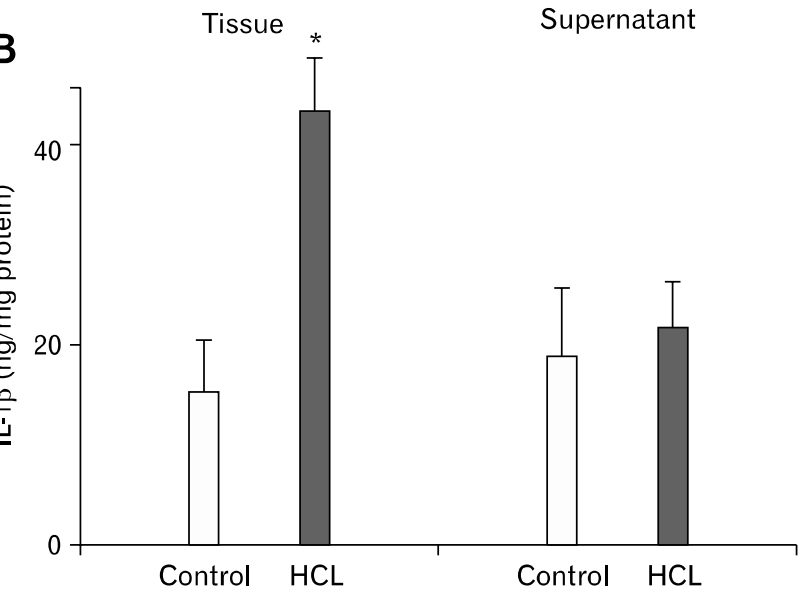

Figure 11. (A) When mucosa was exposed to $\mathrm{HCl}$ (pH 4.0, 3 hours), IL-6 did not significantly increase in the mucosa or in the supernatant surrounding the mucosal sac when compared to normal Krebs-treated mucosa (control) samples. (B) When mucosa was exposed to HCl, IL-1 $\beta$ increased significantly in the mucosa (paired $t$ test, ${ }^{*} \mathrm{p}<0.05$ ) but not in the supernatant surrounding the mucosal sac. IL-6 and IL- $1 \beta$ levels were measured by enzyme immunoassay. Means \pm SEM are shown for 3 esophagus samples. Adapted from Cheng et al. ${ }^{41}$ 
A

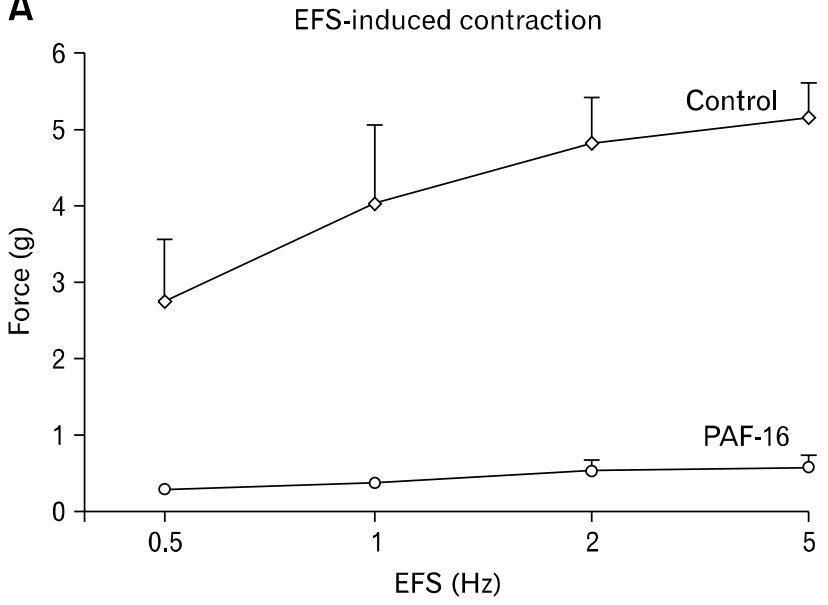

B

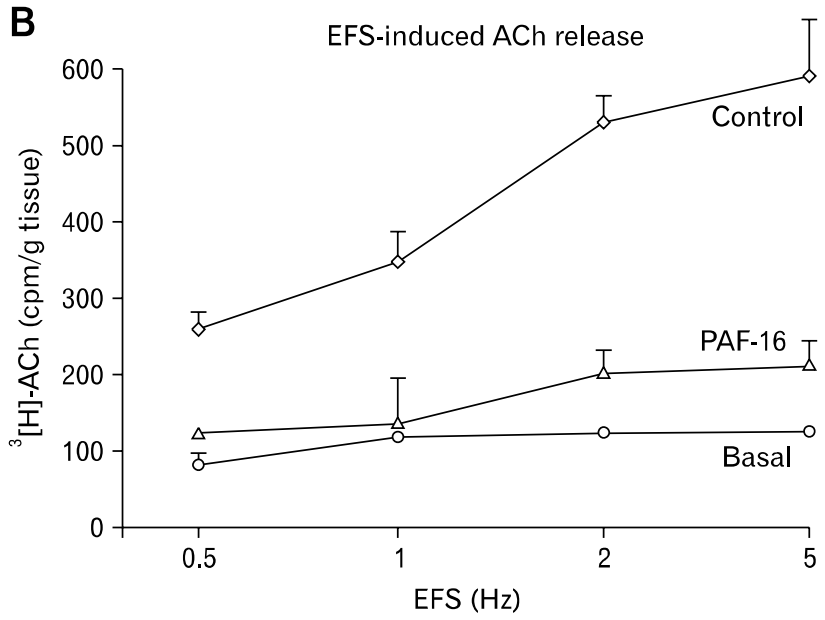

Figure 12. (A) Incubation of normal esophageal smooth muscle strips in the platelet activating factor (PAF) analog PAF-16 (10 $0^{-5} \mathrm{M}, 1-2$ hours) almost abolished contraction in response to electrical field stimulation (EFS) ( $p<0.05$, ANOVA). (B) EFS-induced release of acetylcholine (ACh) from esophageal circular muscle strips is shown as control. Incubation of normal muscle strips in PAF-16 $\left(10^{-5} \mathrm{M}, 1-2\right.$ hours) reduced ACh release to basal levels ( $p<0.05$, ANOVA for comparison of PAF-16 to control), suggesting that PAF inhibits EFS-induced contraction by inhibiting release of ACh. Means \pm SEM are shown for 3 esophagus samples. Adapted from Cheng et al. ${ }^{41}$

of IL-1. ${ }^{41,42} \mathrm{H}_{2} \mathrm{O}_{2}$ and IL-1 can themselves induce PAF production (Fig. 13). This indicates the existence of a self-perpetuating cycle of inflammation and motility abnormalities that is started by $\mathrm{HCl}$-induced $\mathrm{PAF}$ release from the esophageal mucosa.

PAF, IL-1 and IL-6 can independently alter neurogenic esophageal muscle contraction, mostly by inhibiting release of acetylcholine. $^{8,57}$

\section{Role of epithelium in $\mathrm{HCl}$-induced inflammation}

This mucosal sac model contains a variety of different cell types, including epithelial, mesenchymal, neural, etc, that may contribute to the inflammatory process. As epithelial cells, however, have first contact with acid they may play a critical role in the early pathophysiological events leading to GERD. The esophageal epithelium is embryologically, morphologically and functionally related to the skin epithelium, which is recognized as a major immunological organ. ${ }^{58}$ Esophageal keratinocytes most likely serve as the initiating cell type in esophageal inflammation by expressing activation and cell adhesion molecules and by secreting a variety of proinflammatory cytokines that affect leukocyte recruitment and activity. ${ }^{59}$

\section{Chemoattractants and activators of peripheral blood leukocytes}

In addition to affecting circular muscle contraction, PAF induces production of $\mathrm{H}_{2} \mathrm{O}_{2}$ in leukocytes (preferentially in eosino-

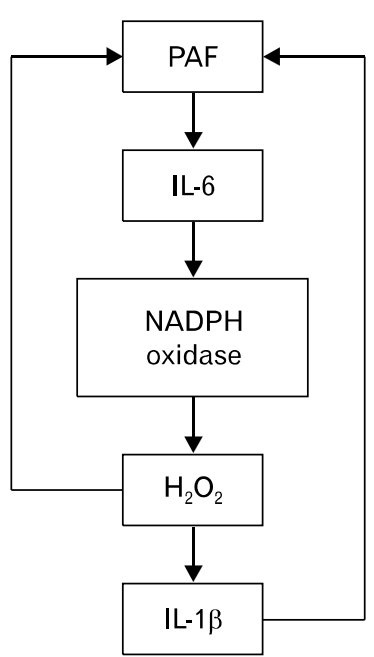

Figure 13. In the circular muscle platelet activating factor (PAF), released by the mucosa causes production of IL-6, that, in turn activates the enzyme nicotinamide adenine dinucleotide phosphate (NADPH) oxidase, inducing production of $\mathrm{H}_{2} \mathrm{O}_{2}$ and IL-1 $\beta$ that, in turn, induce production of PAF by the circular muscle. PAF is only partly produced by IL- $1 \beta$, because the IL- $1 \beta$ antibody partly reduced $\mathrm{PAF}$ formation. The data suggest that $\mathrm{H}_{2} \mathrm{O}_{2}$ may induce formation of PAF directly, and in part through formation of IL- $1 \beta$ (see reference 2 for details). Adapted from Cheng et al. ${ }^{41}$

phils) ${ }^{60}$ and is among the most important inducers of eosinophil function. It is a potent chemoattractant for eosinophils and selectively induces the migration of eosinophils over neutrophils. ${ }^{38,61}$ PAF has an important role in eosinophil transmigration 
through basement membrane components, ${ }^{62}$ it promotes actin polymerization $^{63}$ and eosinophil adherence to vascular endothelial cells $^{64}$ and evokes the release of reactive oxygen species. 39,40

Several studies have reported that in experimental animal models and in human reflux esophagitis, pro-inflammatory cytokine production may underlie the development of erosive esophagitis, ${ }^{8-12}$ which is defined by the infiltration of neutrophils and eosinophils into the submucosa. However, the mechanisms whereby acid exposure and PAF lead to the recruitment of immune cells in the esophageal mucosa are not known.

Several factors have been suggested as being chemotactic for neutrophils and eosinophils. IL-8, a CXC chemokine with potent chemotactic activity for neutrophils, is elevated in the esophageal mucosa of esophagitis patients, ${ }^{11,65}$ suggesting a possible role of IL-8 in the pathogenesis of erosive esophagitis induced by acid reflux. SP is known to be a chemoattractant and activator of lymphocytes, monocytes, mast cells and importantly neutrophils and eosinophils. $^{66}$

We propose that acid in the lumen of the esophagus activates TRPV1 receptors causing the production and release of PAF, SP and CGRP that, in turn, may attract and activate immune cells contributing to inflammation and injury of the esophageal mucosa.

The rabbit has been used extensively ${ }^{67-71}$ as a model for the study of the human esophageal mucosa. Rabbit esophageal mucosa, similarly to cat, ${ }^{72}$ contains TRPV1 receptors and responds to $\mathrm{HCl}$ by producing $\mathrm{SP}, \mathrm{CGRP}$ and PAF. In addition the rabbit esophageal mucosa produces IL-8, that is known to be elevated in GERD and to attract leukocytes, particularly neutrophils. $^{73-77}$

To understand the inflammatory process in the esophagus it is important to establish which inflammatory mediators are released by $\mathrm{HCl}$-stimulated esophageal mucosa at concentrations sufficient to attract and activate peripheral blood leukocytes. Rabbit esophageal mucosa has been used for these experiments. Peripheral blood leukocytes (PBL) were used to examine cell migration in response to the inflammatory mediators/chemokines present in the supernatant of the $\mathrm{HCl}$-stimulated mucosal sac. PBL migration in response to IL-8 and to mucosal supernatant has been examined by using a migration chamber. Figure 14 shows that IL-8 induces PBL migration. PBL migration induced by supernatant of $\mathrm{HCl}$-treated mucosa was comparable to that induced by IL-8. Selective antagonists were used to assess the individual contribution of inflammatory mediators present in the supernatant. The figure shows that a selective CGRP antagonist did not affect
PBL migration. In contrast, a selective IL-8 antibody, a PAF receptor antagonist, and an neurokinin-1 receptor antagonist (ie, SP antagonist) significantly reduced $\mathrm{PBL}$ migration, supporting a role of IL-8, PAF and SP as relevant chemokines.

Activated polymorphonuclear leukocytes (including neutrophils, basophils and eosinophils) have been used as the prototype of cells which vigorously produce superoxide anions ${ }^{78}$ which, in turn, generate other reactive oxygen species (ROS) together with microbiocidal peptides and proteases. ROS comprise species such as superoxide, $\mathrm{H}_{2} \mathrm{O}_{2}$, nitric oxide and hydroxyl radicals. ${ }^{79}$ These highly reactive molecules are known to regulate many im-

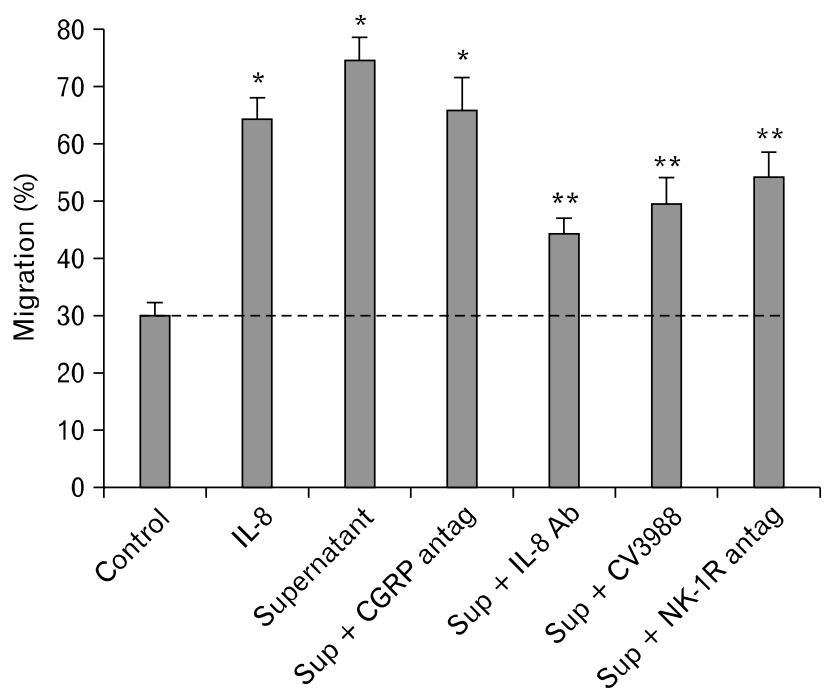

Figure 14. Peripheral blood leukocyte (PBL) migration was examined using a dual chamber motility system, where the upper chamber was separated from the lower chamber by a Polycarbonate track-etch membrane with $3 \mu \mathrm{m}$ pores. Cell migration was allowed to proceed from the upper to the lower chamber for 60 minutes at $37^{\circ} \mathrm{C}$ in a $\mathrm{CO}_{2}$ incubator. The lower chamber contained materials to be tested for their effect on PBL motility. PBL motility was measured with an ATP Luminescence-Based Motility-Invasion assay. PBL migration $\left(60\right.$ minutes at $37^{\circ} \mathrm{C}$ ) was significantly increased by IL-8 $\left(0.5 \times 10^{-9} \mathrm{M}\right)$, as expected, and by the supernatant of the $\mathrm{HCl}(\mathrm{pH}$ $5.0,3$ hours)-filled mucosal sac (* $p<0.05$, ANOVA). When using antagonists or antibodies, cells were pretreated with the antagonist/antibody for 30 minutes before being placed in the upper chamber. The lower chamber contained the same concentration of antagonists or antibodies as the upper chamber. The increased PBL migration was significantly reduced by IL-8 immuno-neutralization by an IL-8 antibody (1:200), by a platelet activating factor receptor antagonist (CV3988, 10 $\left.0^{-5} \mathrm{M}\right)$ and by an neurokinin-1 receptor (NK-1R) antagonist $\left(10^{-5} \mathrm{M}\right)\left({ }^{* *} \mathrm{p}<0.05\right.$, ANOVA $)$. The increased PBL migration was not affected by a calcitonin gene related peptide antagonist (CGRP-[8-37], 10 $0^{-6} \mathrm{M}$ ). Data represent mean \pm SEM of 3 experiments. Adapted from Ma et al. ${ }^{77 a}$ 
portant cellular events, including gene expression, ${ }^{80}$ transcription factor activation, ${ }^{81}$ DNA synthesis ${ }^{82}$ and cellular proliferation. ${ }^{83}$ The enzymes nicotinamide adenine dinucleotide phosphate oxidase (NOX) and dual oxidase generate ROS in a regulated manner, producing reactive oxygen in cells and tissues in response to growth factors, cytokines and calcium signals. ${ }^{84}$

While activated PBL produce inflammatory products other than $\mathrm{H}_{2} \mathrm{O}_{2}, \mathrm{H}_{2} \mathrm{O}_{2}$ may be used as a model for PBL-derived ROS because $\mathrm{H}_{2} \mathrm{O}_{2}$ is physiologically produced in large amounts by cells such as granulocytes, is relatively stable and has been widely used to assess the effects of ROS. ${ }^{79}$

$\mathrm{H}_{2} \mathrm{O}_{2}$ levels, taken as measure of $\mathrm{PBL}$ activation, increased when PBL are exposed to sac supernatant at pH 5 (Fig. 15). The contribution of the individual mediators to PBL activation may be assessed by using the appropriate antagonists. The increase was not affected by a CGRP antagonist or by IL-8 neutralization, suggesting that neither CGRP nor IL-8, at the concentrations present in the supernatant, play a role in inducing $\mathrm{H}_{2} \mathrm{O}_{2}$ production by PBL. In contrast, a PAF antagonist and a neurokinin-1 receptor antagonist (ie, SP antagonist) significantly reduce supernatant-induced $\mathrm{H}_{2} \mathrm{O}_{2}$ production.

Thus the inflammatory mediators produced by $\mathrm{HCl}$ exposure may act as chemokines, as immune cells activators, or both. In our system, IL- 8 acts only as a chemokine, substance P and PAF act as both chemokines and activators, CGRP, does neither. The data suggest that PBL migration and $\mathrm{H}_{2} \mathrm{O}_{2}$ production may be different functions, possibly depending on different signal transduction pathways.

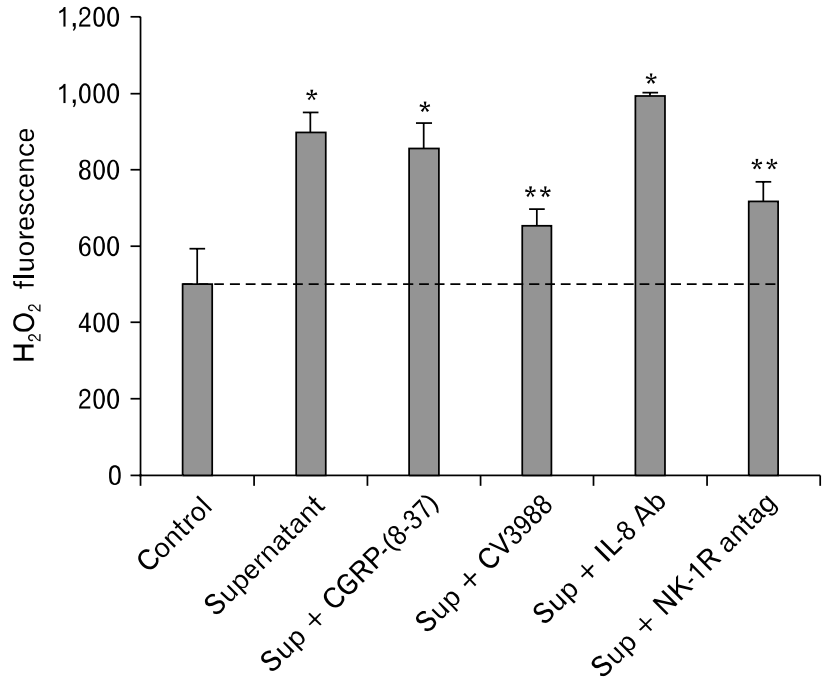

Figure 15. To examine the effect of mucosal supernatant on $\mathrm{H}_{2} \mathrm{O}_{2}$ production, peripheral blood leukocyte (PBL) were incubated for 20 minutes at $37^{\circ} \mathrm{C}$ in mucosal supernatant from sac incubated in Krebs buffer alone (control) or in acidified Krebs buffer (pH 5.0, 3 hours) (supernatant). The supernatant of the acidified mucosal sac caused a 2-fold increase in $\mathrm{H}_{2} \mathrm{O}_{2}$ production by $\mathrm{PBL}$ ( ${ }^{*} \mathrm{p}<0.05$, ANOVA). When using antagonists or antibodies, $\mathrm{PBL}$ were pretreated with the antagonist/antibody for 30 minutes before exposure to the supernatant. The increase in $\mathrm{H}_{2} \mathrm{O}_{2}$ levels was not affected by a calcitonin gene related peptide antagonist (CGRP-[8-37], 10-6 M) or by IL-8 immuno-neutralization by an IL-8 antibody (1:200). The increased $\mathrm{H}_{2} \mathrm{O}_{2}$ levels, however, were significantly reduced by a platelet activating factor receptor antagonist $\left(\mathrm{CV} 3988,10^{-5} \mathrm{M}\right)$ and by an neurokinin-1 receptor $(\mathrm{NK}-1 \mathrm{R})$ antagonist $\left(10^{-5} \mathrm{M}\right)(* * \mathrm{p}<0.05$, ANOVA). Data represent mean \pm SEM of 8 experiments. Adapted from $\mathrm{Ma}$ et al. ${ }^{77 a}$
A

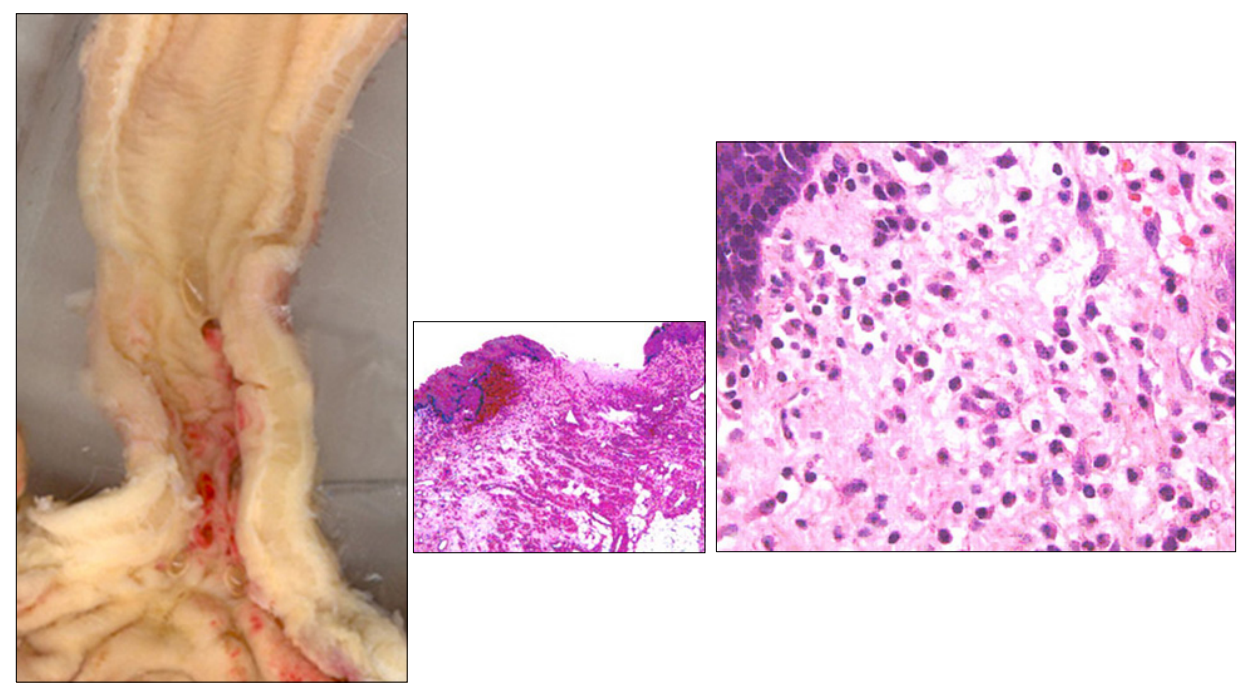

Figure 16. An esophageal specimen obtained from an organ donor exhibited hyperemia of the mucosa with scattered hemorrhagic erosions in the lower esophagus, extending across the cardia. (A) Gross finging shows erosions, basal zone hyperplasia and elongation of lamina propria papillae with congestion. The enlarged area (B) shows inflammatory cells present in the epithelial layer. These findings are characteristic of reflux esophagitis. Modified from Cheng et al. ${ }^{85}$ 
These results, derived from an ex vivo model mimicking reflux-induced events in vivo, identifies the type and quantity of inflammatory mediators likely produced in GERD. Since cellular immune infiltrate is a prerequisite for severe inflammation and tissue damage, inhibition of IL-8, SP and PAF-induced PBL migration and activation may provide potential targets for therapy.

\section{Chronic Esophagitis: Role of Platelet Activating Factor and Hydrogen Peroxide}

The previous data were obtained in normal human and animal esophageal specimens after short (3 hours) exposure of esophageal mucosa to acid, and short (3 hours) exposure of circular muscle to mucosa supernatant. To examine whether the data may also be applicable to chronic esophagitis, we refer to a human organ donor specimen with histologically demonstrated erosive esophagitis (Fig. 16). ${ }^{85}$ In this specimen, the circular muscle was taken from the lower esophageal sphincter (LES). Essentially the same inflammatory processes are present in the body of the esophagus and in the LES. This is not surprising as the inflammation begins with damage to the epithelial cells in the mucosa, that are not different from epithelial cells in the body of the esophagus.

When mounted in a warm $\left(37^{\circ} \mathrm{C}\right)$ oygenated muscle cham- ber, normal-LES circular muscle strips gradually develop tone and reach a steady state tone after 3-4 hours. In contrast, circular muscle strips from esophagitis LES develop little tone, falling

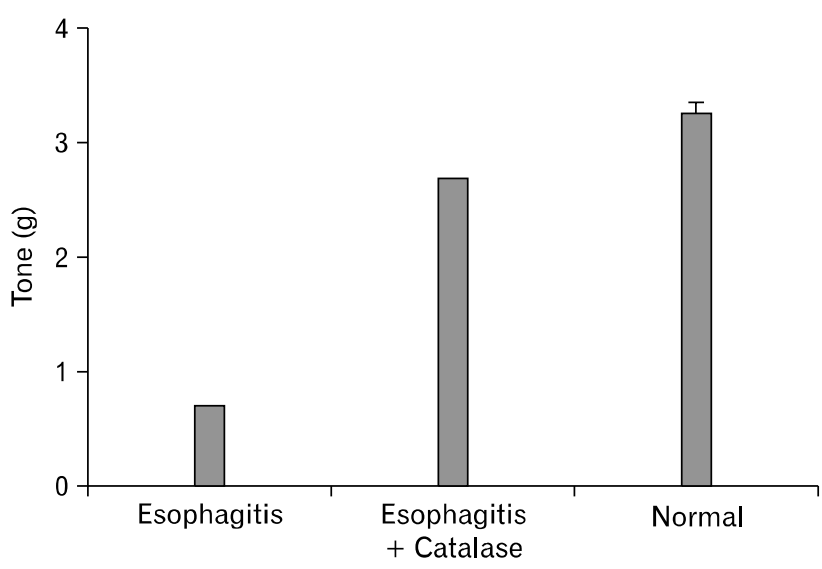

Figure 17. Circular muscle strips were mounted in muscle chambers, stretched to $2.5 \mathrm{~g}$ to bring them near conditions of optimum force development, and equilibrated for 4-6 hours while perfused continuously with oxygenated physiologic salt solution at $37^{\circ} \mathrm{C}$. During this time the tension in lower esophageal sphincter (LES) strips increased, attaining a steady level at 3-4 hours. In LES circular muscle strips from the esophagitis specimen obtained from an organ donor, tone was lower than in normal strips. $\mathrm{H}_{2} \mathrm{O}_{2}$ treatment of muscle strips from the esophagitis specimen with the scavenger catalase $(800 \mathrm{U} / \mathrm{mL})$ for 30 min significantly increased LES tone, almost to a normal level. These data indicate that $\mathrm{H}_{2} \mathrm{O}_{2}$ may be responsible for the reduced tone in esophagitis. Means \pm SEM are shown for 3 normal LES samples. Modified from Cheng et al. ${ }^{85}$
A

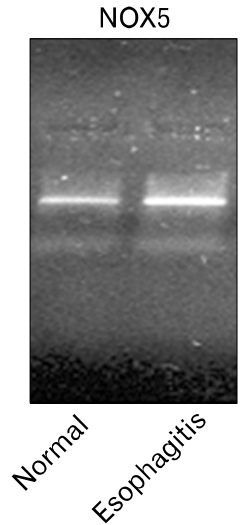

B

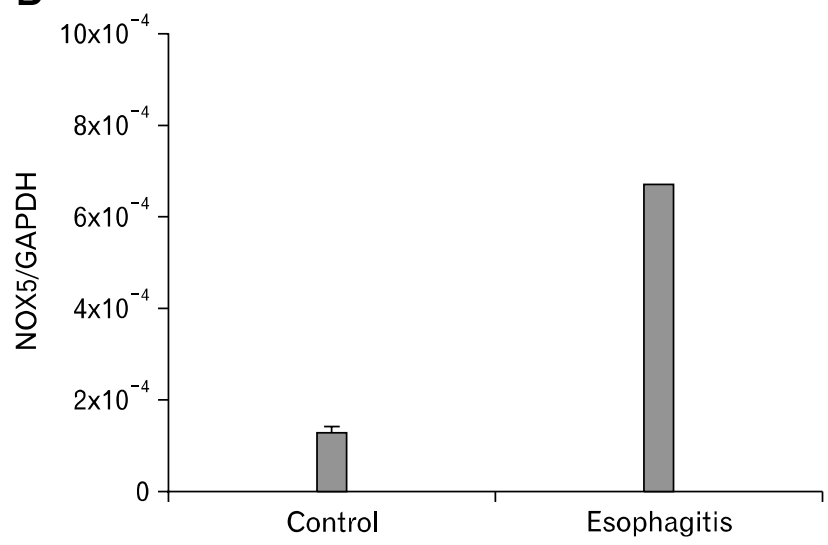

Figure 18. Lower esophageal sphincter (LES) circular muscle was examined by reverse transcriptase-polymerase chain reaction (RT-PCR) for the presence of nicotinamide adenine dinucleotide phosphate (NADPH) oxidases. We used published primers for NOX1-NOX5, and found that these components of the NADPH oxidase enzyme are all present in esophageal circular muscle, but only NOX5 mRNA was increased in the human specimen with esophagitis, as shown in (A). Increased NOX 5 cDNA in the esophagitis specimen was confirmed by real-time RT-PCR, when compared to normal human esophageal circular muscle, as shown in (B). Means \pm SEM are shown for 3 normal (control) and for 3 IL- $1 \beta$-treated LES samples. Modified from Cheng et al. ${ }^{85}$ 
outside of the normal tone minus 2 standard deviations. When circular muscle strips from the esophagitis LES were exposed to the $\mathrm{H}_{2} \mathrm{O}_{2}$ scavenger catalase, tone increased and reached a value similar to that of strips from normal LES (Fig. 17). These findings suggest that $\mathrm{H}_{2} \mathrm{O}_{2}$ may be present in circular muscle of esophagitis LES, and responsible for reduced tone when inflammation is present.

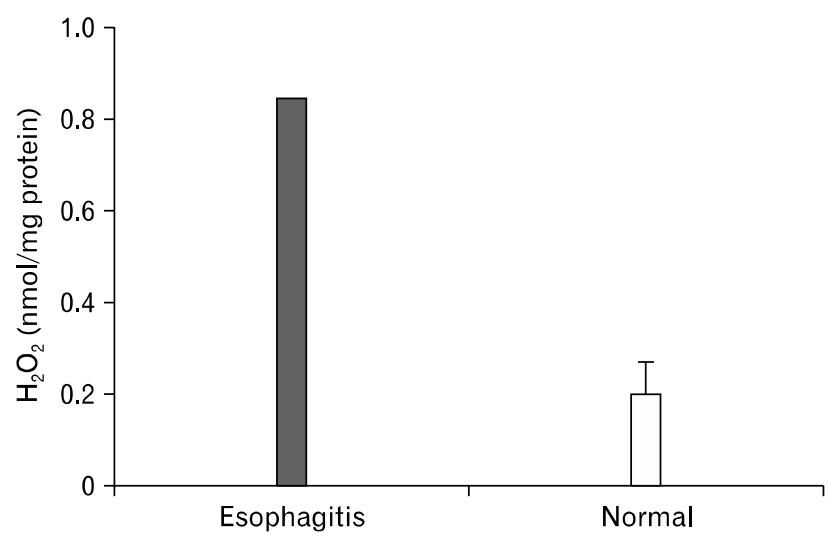

Figure 19. Esophagitis increases $\mathrm{H}_{2} \mathrm{O}_{2}$ treatment of muscle strips from the esophagitis specimen with the levels in lower esophageal sphincter (LES) circular smooth muscle, as measured by a colorimetric assay. $\mathrm{H}_{2} \mathrm{O}_{2}$ levels were 4-fold higher in LES muscle from the esophagitis specimen compared with normal muscle. Means \pm SEM are shown for 3 normal LES samples. Modified from Cheng et al. ${ }^{85}$

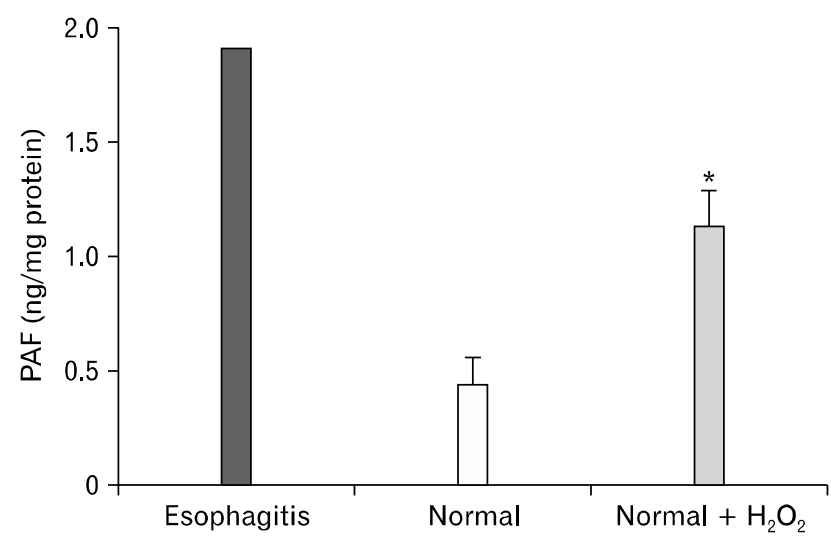

Figure 20. Esophagitis and $\mathrm{H}_{2} \mathrm{O}_{2}$ increase platelet activating factor (PAF) production in lower esophageal sphincter (LES). The PAF concentration was quantified by using a ${ }^{3}[\mathrm{H}]$ PAF scintillation proximity assay system (Amersham Pharmacia Biotech Inc, Princeton, NJ, USA). In esophagitis circular muscle PAF levels were four times higher than in normal LES. In normal LES muscle, PAF levels were significantly increased $\left({ }^{*} \mathrm{p}<0.01\right.$, unpaired $t$ test) by $\mathrm{H}_{2} \mathrm{O}_{2}$ (70 mM, 2 hours). Modified from Cheng et al. ${ }^{85}$
Upregulation of NOXs is a possible mechanism for overproduction of $\mathrm{H}_{2} \mathrm{O}_{2}$. The NOXs present in human esophageal circular muscle, and possibly upregulated by esophagitis were examined by RT-PCR. Whereas NOX1-NOX5 are all present in esophageal circular muscle, only NOX 5 mRNA was increased in the human specimen with esophagitis, as shown in Figure 18A. Increased NOX 5 mRNA in the esophagitis specimen was confirmed by real-time RT-PCR, when compared to normal human esophageal circular muscle, as shown in Figure 18B.

Figure 19 shows $\mathrm{H}_{2} \mathrm{O}_{2}$ levels in normal and esophagitis circular muscle tissue. Basal $\mathrm{H}_{2} \mathrm{O}_{2}$ levels were elevated in circular muscle of esophagitis LES, exceeding normal levels by more than 2 standard deviations.

PAF levels were elevated in the circular muscle of the human esophagitis sample and exceeded those of the normal sample by more than 2 standard deviations (Fig. 20). Incubation of normal LES circular muscle in $\mathrm{H}_{2} \mathrm{O}_{2}$ (70 M, 2 hours) significantly increased PAF levels $(\mathrm{p}<0.01)$.

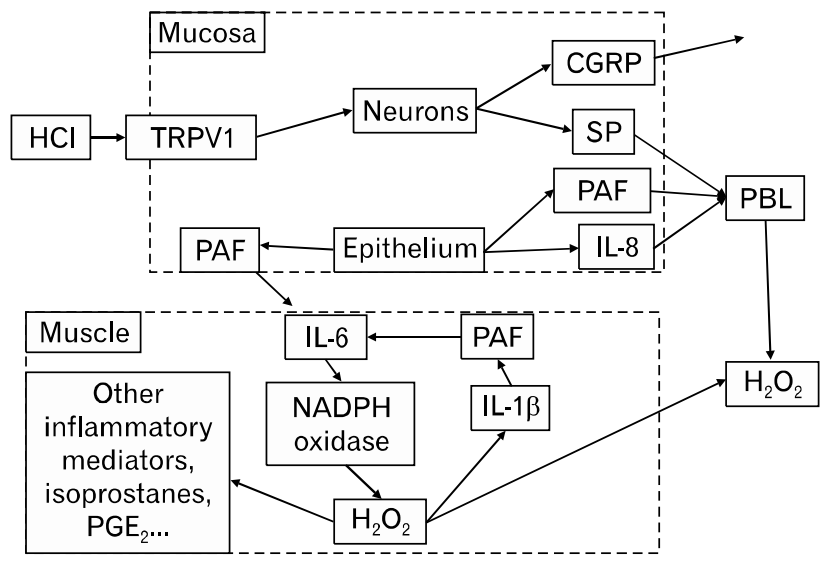

Figure 21. The data suggest that exposure of esophageal mucosa to acid activates transient receptor potential channel vanilloid subfamily member-1 receptors, inducing neurally-mediated formation of substance $\mathrm{P}(\mathrm{SP})$ and calcitonin gene related peptide and production of platelet activating factor (PAF), IL-8 and probably other cytokines by the epithelium. SP, PAF and IL-8 behave as chemoattactants for peripheral blood leukocytes. In addition, $\mathrm{SP}$ and PAF activate immune cells to produce $\mathrm{H}_{2} \mathrm{O}_{2}$. In the circular muscle layer, $\mathrm{PAF}$ alone is sufficient to almost completely inhibit release of acetylcholine (ACh) from cholinergic neurons, thus inhibiting esophageal circular muscle contraction. In addition, $\mathrm{PAF}$ induces sequential production of IL-6, $\mathrm{H}_{2} \mathrm{O}_{2}$, IL-1 $\beta$ and PAF in the circular muscle, all contributing to reduction of esophageal contraction and esophageal sphincter tone. TRPV1, transient receptor potential channel vanilloid subfamily member-1; CGRP, calcitonin gene related peptide; PBL, peripheral blood leukocyte; NADPH, nicotinamide adenine dinucleotide phosphate. 


\section{Conclusion}

Epithelial cells, not only constitute the first barrier to diffusion of refluxate, but are important participants in inflammation as they respond to $\mathrm{HCl}$-mediated activation of TRPV 1 by releasing cytokines and inflammatory mediators. Cytokines and inflammatory mediators may diffuse to the circular muscle layer affecting contraction and may attract and activate immune cells. PAF and IL-8 produced by epithelial cells, together with SP released from submucosal neurons attract peripheral blood leukocytes, that are activated by both PAF and SP to produce $\mathrm{H}_{2} \mathrm{O}_{2}$. $\mathrm{H}_{2} \mathrm{O}_{2}$ is uncharged, freely diffusible through cellular membranes, and likely to interact with membrane lipids, causing lipid peroxidation and peroxidation-induced inflammatory mediators. $\mathrm{H}_{2} \mathrm{O}_{2}$ may contribute to further production of $\mathrm{PAF}$ and cause upregulation of NOX in the mucosa and muscle. $\mathrm{H}_{2} \mathrm{O}_{2}$ may also interact with DNA bases (more than 20 different oxidatively altered purines and pyrimidines have been detected and characterized), ${ }^{86}$ perhaps inducing alterations of cell phenotype and possibly resulting in permanent mutations. The data are summarized in Figure 21.

\section{References}

1. Fass R. Erosive esophagitis and nonerosive reflux disease (NERD): comparison of epidemiologic, physiologic, and therapeutic characteristics. J Clin Gastroenterol 2007;41:131-137.

2. Locke GR 3rd, Talley NJ, Fett SL, Zinsmeister AR, Melton LJ 3rd. Prevalence and clinical spectrum of gastroesophageal reflux: a population-based study in Olmsted County, Minnesota. Gastroenterology 1997;112:1448-1456.

3. Moayyedi P, Talley NJ. Gastro-oesophageal reflux disease. Lancet 2006;367:2086-2100.

4. Orlando RC. Reflux esophagitis: overview. Scand J Gastroenterol 1995;210(suppl):36-37.

5. Orlando RC. Pathophysiology of gastroesophageal reflux disease. J Clin Gastroenterol 2008;42:584-588.

6. Livstone EM, Sheahan DG, Behar J. Studies of esophageal epithelial cell proliferation in patients with reflux esophagitis. Gastroenterology 1977;73:1315-1319.

7. Souza RF, Huo X, Mittal V, et al. Gastroesophageal reflux might cause esophagitis through a cytokine-mediated mechanism rather than caustic acid injury. Gastroenterology 2009;137:1776-1784.

8. Cao W, Cheng L, Behar J, Fiocchi C, Biancani P, Harnett KM. Proinflammatory cytokines alter/reduce esophageal circular muscle contraction in experimental cat esophagitis. Am J Physiol Gastrointest Liver Physiol 2004;287:G1131-G1139.

9. Cheng L, Cao W, Fiocchi C, Behar J, Biancani P, Harnett KM. In vitro model of acute esophagitis in the cat. Am J Physiol Gastrointest
Liver Physiol 2005;289:G860-G869.

10. Fitzgerald RC, Onwuegbusi BA, Bajaj-Elliott M, Saeed IT, Burnham WR, Farthing MJ. Diversity in the oesophageal phenotypic response to gastro-oesophageal reflux: immunological determinants. Gut 2002;50:451-459.

11. Isomoto H, Wang A, Mizuta Y, et al. Elevated levels of chemokines in esophageal mucosa of patients with reflux esophagitis. Am J Gastroenterol 2003;98:551-556.

12. Yoshida N, Uchiyama K, Kuroda M, et al. Interleukin-8 expression in the esophageal mucosa of patients with gastroesophageal reflux disease. Scand J Gastroenterol 2004;39:816-822.

13. Paterson WG, Kieffer CA, Feldman MJ, Miller DV, Morris GP. Role of platelet-activating factor in acid-induced esophageal mucosal injury. Dig Dis Sci 2007;52:1861-1866.

14. Rieder F, Biancani P, Harnett K, Yerian L, Falk GW. Inflammatory mediators in gastroesophageal reflux disease: impact on esophageal motility, fibrosis, and carcinogenesis. Am J Physiol Gastrointest Liver Physiol 2010;298:G571-G581.

15. Szallasi A, Blumberg PM. Vanilloid (Capsaicin) receptors and mechanisms. Pharmacol Rev 1999;51:159-212.

16. Cortright DN, Szallasi A. Biochemical pharmacology of the vanilloid receptor TRPV1. An update. Eur J Biochem 2004;271:1814-1819.

17. Yiangou Y, Facer P, Dyer NH, et al. Vanilloid receptor 1 immunoreactivity in inflamed human bowel. Lancet 2001;357:1338-1339.

18. Chan CL, Facer P, Davis JB, et al. Sensory fibres expressing capsaicin receptor TRPV1 in patients with rectal hypersensitivity and faecal urgency. Lancet 2003;361:385-391.

19. Matthews PJ, Aziz Q, Facer P, Davis JB, Thompson DG, Anand P. Increased capsaicin receptor TRPV1 nerve fibres in the inflamed human oesophagus. Eur J Gastroenterol Hepatol 2004;16:897-902.

20. Guarino MP, Cheng L, Ma J, et al. Increased TRPV1 gene expression in esophageal mucosa of patients with non-erosive and erosive reflux disease. Neurogastroenterol Motil 2010;22:746-751, e219.

21. Veronesi B, Carter JD, Devlin RB, Simon SA, Oortgiesen M. Neuropeptides and capsaicin stimulate the release of inflammatory cytokines in a human bronchial epithelial cell line. Neuropeptides 1999;33:447-456.

22. Mantyh CR, Maggio JE, Mantyh PW, Vigna SR, Pappas TN. Increased substance $\mathrm{P}$ receptor expression by blood vessels and lymphoid aggregates in Clostridium difficile-induced pseudomembranous colitis. Dig Dis Sci 1996;41:614-620.

23. Mantyh CR, McVey DC, Vigna SR. Extrinsic surgical denervation inhibits Clostridium difficile toxin A-induced enteritis in rats. Neurosci Lett 2000;292:95-98.

24. Mantyh CR, Pappas TN, Lapp JA, et al. Substance P activation of enteric neurons in response to intraluminal Clostridium difficile toxin A in the rat ileum. Gastroenterology 1996;111:1272-1280.

25. Mantyh CR, Vigna SR, Bollinger RR, Mantyh PW, Maggio JE, Pappas TN. Differential expression of substance $P$ receptors in patients with Crohn's disease and ulcerative colitis. Gastroenterology 1995; 109:850-860.

26. Mantyh PW, DeMaster E, Malhotra A, et al. Receptor endocytosis and dendrite reshaping in spinal neurons after somatosensory stimulation. Science 1995;268:1629-1632.

27. McVey DC, Schmid PC, Schmid HH, Vigna SR. Endocannabi- 
noids induce ileitis in rats via the capsaicin receptor (VR1). J Pharmacol Exp Ther 2003;304:713-722.

28. McVey DC, Vigna SR. The capsaicin VR1 receptor mediates substance $\mathrm{P}$ release in toxin A-induced enteritis in rats. Peptides 2001;22:1439-1446.

29. McVey DC, Vigna SR. The role of leukotriene B4 in Clostridium difficile toxin A-induced ileitis in rats. Gastroenterology 2005;128: 1306-1316.

30. Nathan JD, Patel AA, McVey DC, et al. Capsaicin vanilloid receptor-1 mediates substance $\mathrm{P}$ release in experimental pancreatitis. Am J Physiol Gastrointest Liver Physiol 2001;281:G1322-G1328.

31. Nathan JD, Peng RY, Wang Y, McVey DC, Vigna SR, Liddle RA. Primary sensory neurons: a common final pathway for inflammation in experimental pancreatitis in rats. Am J Physiol Gastrointest Liver Physiol 2002;283:G938-G946.

32. Barbara G, De Giorgio R, Stanghellini V, et al. Neutral endopeptidase (EC 3.4.24.11) downregulates the onset of intestinal inflammation in the nematode infected mouse. Gut 2003;52:14571464.

33. Kirkwood KS, Bunnett NW, Maa J, et al. Deletion of neutral endopeptidase exacerbates intestinal inflammation induced by Clostridium difficile toxin A. Am J Physiol Gastrointest Liver Physiol 2001; 281:G544-G551.

34. Sturiale S, Barbara G, Qiu B, et al. Neutral endopeptidase (EC 3.4.24.11) terminates colitis by degrading substance P. Proc Natl Acad Sci USA 1999;96:11653-11658.

35. Kimball ES, Wallace NH, Schneider CR, D'Andrea MR, Hornby PJ. Vanilloid receptor 1 antagonists attenuate disease severity in dextran sulphate sodium-induced colitis in mice. Neurogastroenterol Motil 2004;16:811-818.

36. Kihara N, de la Fuente SG, Fujino K, Takahashi T, Pappas TN, Mantyh CR. Vanilloid receptor-1 containing primary sensory neurones mediate dextran sulphate sodium induced colitis in rats. Gut 2003;52:713-719.

37. Fujino K, de la Fuente SG, Takami Y, Takahashi T, Mantyh CR. Attenuation of acid induced oesophagitis in VR-1 deficient mice. Gut 2006;55:34-40.

38. Wardlaw AJ, Moqbel R, Cromwell O, Kay AB. Platelet-activating factor. A potent chemotactic and chemokinetic factor for human eosinophils. J Clin Invest 1986;78:1701-1706.

39. Shute JK, Rimmer SJ, Akerman CL, Church MK, Holgate ST. Studies of cellular mechanisms for the generation of superoxide by guinea-pig eosinophils and its dissociation from granule peroxidase release. Biochem Pharmacol 1990;40:2013-2021.

40. Zoratti EM, Sedgwick JB, Vrtis RR, Busse WW. The effect of platelet-activating factor on the generation of superoxide anion in human eosinophils and neutrophils. J Allergy Clin Immunol 1991;88:749758.

41. Cheng L, Cao W, Behar J, Fiocchi C, Biancani P, Harnett KM. Acid-induced release of platelet-activating factor by human esophageal mucosa induces inflammatory mediators in circular smooth muscle. J Pharmacol Exp Ther 2006;319:117-126.

42. Cheng L, Cao W, Fiocchi C, Behar J, Biancani P, Harnett KM. $\mathrm{HCl}$-induced inflammatory mediators in cat esophageal mucosa and inflammatory mediators in esophageal circular muscle in an in vitro model of esophagitis. Am J Physiol Gastrointest Liver Physiol
2006;290:G1307-G1317.

43. Southall MD, Li T, Gharibova LS, Pei Y, Nicol GD, Travers JB. Activation of epidermal vanilloid receptor-1 induces release of proinflammatory mediators in human keratinocytes. J Pharmacol Exp Ther 2003;304:217-222.

44. Ständer S, Moormann C, Schumacher M, et al. Expression of vanilloid receptor subtype 1 in cutaneous sensory nerve fibers, mast cells, and epithelial cells of appendage structures. Exp Dermatol 2004;13:129-139.

45. Birder LA, Kanai AJ, de Groat WC, et al. Vanilloid receptor expression suggests a sensory role for urinary bladder epithelial cells. Proc Natl Acad Sci USA 2001;98:13396-13401.

46. Birder LA, Nakamura $\mathrm{Y}$, Kiss $\mathrm{S}$, et al. Altered urinary bladder function in mice lacking the vanilloid receptor TRPV1. Nat Neurosci 2002;5:856-860.

47. Reilly CA, Taylor JL, Lanza DL, Carr BA, Crouch DJ, Yost GS. Capsaicinoids cause inflammation and epithelial cell death through activation of vanilloid receptors. Toxicol Sci 2003;73:170-181.

48. Heiner I, Eisfeld J, Halaszovich CR, et al. Expression profile of the transient receptor potential (TRP) family in neutrophil granulocytes: evidence for currents through long TRP channel 2 induced by ADP-ribose and NAD. Biochem J 2003;371:1045-1053.

49. Chen CW, Lee ST, Wu WT, Fu WM, Ho FM, Lin WW. Signal transduction for inhibition of inducible nitric oxide synthase and cyclooxygenase- 2 induction by capsaicin and related analogs in macrophages. Br J Pharmacol 2003;140:1077-1087.

50. Vaccaro DE. Applications of magnetic separation: cell sorting. Am Biotechnol Lab 1990;8:30, 32-35.

51. Nagano S, Huang X, Moir RD, Payton SM, Tanzi RE, Bush AI. Peroxidase activity of cyclooxygenase-2 (COX-2) cross-links beta-amyloid (Abeta) and generates Abeta-COX-2 hetero-oligomers that are increased in Alzheimer's disease. J Biol Chem 2004; 279:14673-14678.

52. Deaton J, Savva CG, Sun J, Holzenburg A, Berry J, Young R. Solubilization and delivery by GroEL of megadalton complexes of the lambda holin. Protein Sci 2004;13:1778-1786.

53. Dutta S, Haynes JD, Moch JK, Barbosa A, Lanar DE. Invasion-inhibitory antibodies inhibit proteolytic processing of apical membrane antigen 1 of Plasmodium falciparum merozoites. Proc Natl Acad Sci USA 2003;100:12295-122300.

54. Chaudhuri TK, Farr GW, Fenton WA, Rospert S, Horwich AL. GroEL/GroES-mediated folding of a protein too large to be encapsulated. Cell 2001;107:235-246.

55. Ilver D, Arnqvist A, Ogren J, et al. Helicobacter pylori adhesin binding fucosylated histo-blood group antigens revealed by retagging. Science 1998;279:373-377.

56. Ma J, Harnett KM, Behar J, Biancani P, Cao W. Signaling in TRPV1-induced platelet activating factor (PAF) in human esophageal epithelial cells. Am J Physiol Gastrointest Liver Physiol 2010;298:G233-G240.

57. Cheng L, Cao W, Fiocchi C, Behar J, Biancani P, Harnett KM. Platelet-activating factor and prostaglandin E2 impair esophageal ACh release in experimental esophagitis. Am J Physiol Gastrointest Liver Physiol 2005;289:G418-G428.

58. Williams IR, Kupper TS. Immunity at the surface: homeostatic mechanisms of the skin immune system. Life Sci 1996;58:1485- 
1507.

59. Irnich H, Geissel H, Nolden F, et al. Half-life measurements of bare, mass-resolved isomers in a storage-cooler ring. Phys Rev Lett $1995 ; 75: 4182-4185$.

60. Kato M, Kita H, Tachibana A, Hayashi Y, Tsuchida Y, Kimura H. Dual signaling and effector pathways mediate human eosinophil activation by platelet-activating factor. Int Arch Allergy Immunol 2004;134(suppl 1):37-43.

61. Sigal CE, Valone FH, Holtzman MJ, Goetzl EJ. Preferential human eosinophil chemotactic activity of the platelet-activating factor (PAF) 1-0-hexadecyl-2-acetyl-sn-glyceryl-3-phosphocholine (AGEPC). J Clin Immunol 1987;7:179-184.

62. Okada S, Kita H, George TJ, Gleich GJ, Leiferman KM. Transmigration of eosinophils through basement membrane components in vitro: synergistic effects of platelet-activating factor and eosinophil-active cytokines. Am J Respir Cell Mol Biol 1997;16:455-463.

63. Suzuki M, Kato M, Hanaka H, Izumi T, Morikawa A. Actin assembly is a crucial factor for superoxide anion generation from adherent human eosinophils. J Allergy Clin Immunol 2003;112:126-133.

64. Kimani G, Tonnesen MG, Henson PM. Stimulation of eosinophil adherence to human vascular endothelial cells in vitro by platelet-activating factor. J Immunol 1988;140:3161-3166.

65. Isomoto H, Saenko VA, Kanazawa Y, et al. Enhanced expression of interleukin-8 and activation of nuclear factor kappa-B in endoscopy-negative gastroesophageal reflux disease. Am J Gastroenterol 2004;99:589-597.

66. O'Connor TM, O'Connell J, O'Brien DI, Goode T, Bredin CP, Shanahan $\mathrm{F}$. The role of substance $\mathrm{P}$ in inflammatory disease. J Cell Physiol 2004;201:167-180.

67. Tobey NA, Orlando RC. Mechanisms of acid injury to rabbit esophageal epithelium. Role of basolateral cell membrane acidification. Gastroenterology 1991;101:1220-1228.

68. Carney CN, Orlando RC, Powell DW, Dotson MM. Morphologic alterations in early acid-induced epithelial injury of the rabbit esophagus. Lab Invest 1981;45:198-208.

69. Orlando RC, Powell DW, Carney CN. Pathophysiology of acute acid injury in rabbit esophageal epithelium. J Clin Invest 1981;68: 286-293.

70. Lanas A, Royo Y, Ortego J, Molina M, Sáinz R. Experimental esophagitis induced by acid and pepsin in rabbits mimicking human reflux esophagitis. Gastroenterology 1999;116:97-107.

71. Naya MJ, Pereboom D, Ortego J, Alda JO, Lanas A. Superoxide anions produced by inflammatory cells play an important part in the pathogenesis of acid and pepsin induced oesophagitis in rabbits. Gut 1997;40:175-181.
72. Cheng L, de la Monte S, Ma J, et al. HCl-activated neural and epithelial vanilloid receptors (TRPV1) in cat esophageal mucosa. Am J Physiol Gastrointest Liver Physiol 2009;297:G135-G143.

73. Mukaida N. Interleukin-8: an expanding universe beyond neutrophil chemotaxis and activation. Int J Hematol 2000;72:391-398.

74. Zeilhofer HU, Schorr W. Role of interleukin-8 in neutrophil signaling. Curr Opin Hematol 2000;7:178-182.

75. Baggiolini M, Clark-Lewis I. Interleukin-8, a chemotactic and inflammatory cytokine. FEBS Lett 1992;307:97-101.

76. Harada A, Sekido N, Akahoshi T, Wada T, Mukaida N, Matsushima K. Essential involvement of interleukin-8 (IL-8) in acute inflammation. J Leukoc Biol 1994;56:559-564.

77. Zwahlen R, Walz A, Rot A. In vitro and in vivo activity and pathophysiology of human interleukin-8 and related peptides. Int Rev Exp Pathol 1993;34 Pt B:27-42.

77a. Ma J, Altomare A, de la Monte SM, et al. HCl-induced inflammatory mediators in esophageal mucosa increase migration and production of $\mathrm{H}_{2} \mathrm{O}_{2}$ by peripheral blood leukocytes. Am J Physiol Gastrointest Liver Physiol 2010;299:G791-G798.

78. Karnovsky MJ. Robert Feulgen Lecture 1994. Cytochemistry and reactive oxygen species: a retrospective. Histochemistry 1994;102: $15-27$.

79. Halliwell B, Gutteridge JM. Role of free radicals and catalytic metal ions in human disease: an overview. Methods Enzymol 1990; 186:1-85.

80. Nose K, Shibanuma M, Kikuchi K, Kageyama H, Sakiyama S, Kuroki T. Transcriptional activation of early-response genes by hydrogen peroxide in a mouse osteoblastic cell line. Eur J Biochem 1991;201:99-106.

81. Schreck R, Rieber P, Baeuerle PA. Reactive oxygen intermediates as apparently widely used messengers in the activation of the NF-kappa B transcription factor and HIV-1. EMBO J 1991;10:2247-2258.

82. Klaunig JE, Xu Y, Isenberg JS, et al. The role of oxidative stress in chemical carcinogenesis. Environ Health Perspect 1998;106(suppl 1):289-295

83. Murrell GA, Francis MJ, Bromley L. Modulation of fibroblast proliferation by oxygen free radicals. Biochem J 1990;265:659-665.

84. Lambeth JD. NOX enzymes and the biology of reactive oxygen. Nat Rev Immunol 2004;4:181-189.

85. Cheng L, Harnett KM, Cao W, et al. Hydrogen peroxide reduces lower esophageal sphincter tone in human esophagitis. Gastroenterology 2005;129:1675-1685.

86. Dizdaroglu M. Oxidative damage to DNA in mammalian chromatin. Mutat Res 1992;275:331-342. 